\title{
Root coverage procedures for treating single and multiple recession-type defects: A Cochrane Systematic Review Updated
}

Leandro Chambrone, ${ }^{*}$ Maria Aparecida Salinas Ortega, ${ }^{*}$ Flávia Sukekava, ${ }^{\dagger}$ Roberto Rotundo, ${ }^{\ddagger}$ Zamira Kalemaj, ${ }^{\S}$ Jacopo Buti ${ }^{\ddagger}$ and Giovan Paolo Pini Prato"

*MSc Dentistry Program, Ibirapuera University, São Paulo, Brazil

${ }^{\dagger}$ Private practice, Curitiba, Brazil

‡ Unit of Periodontology, UCL Eastman Dental Institute, London, UK

\$Private practice, Milan, Italy

"Tuscany Academy of Dental Research (ATRO), Florence, Italy

This paper is based on a Cochrane Review ${ }^{1}$ published in The Cochrane Library 2018, Issue 10 (see www.thecochranelibrary.com for information). Cochrane Reviews are regularly updated as new evidence emerges and in response to feedback, and The Cochrane Library should be consulted for the most recent version of the review

Correspondence :

Dr. Leandro Chambrone, Rua da Moóca, 2518, cj13

03104-002, São Paulo, SP, Brazil.

E-mail:leandro_chambrone@hotmail.com

Words: 3,887 Number of tables: 3 Number of Figures: 2 References: 83

Number of online supplemental appendixes: 8

Short running title: Treatment of recession type-defects

Summary sentence: Subepithelial connective tissue grafts, coronally advanced flaps alone or associated with other allogenous/xenogenous soft tissue substitutes can be used as root coverage procedures for the treatment of recession-type defects

\section{ABSTRACT}

This article is protected by copyright. All rights reserved. 
Background: This updated Cochrane systematic review (SR) evaluated the efficacy of different root coverage $(\mathrm{RC})$ procedures in the treatment of single and multiple gingival recessions (GR).

Material and Methods: We included randomized controlled trials (RCTs) only of at least 6 months' duration evaluating Miller's Class I or II GR ( $\geq 3 \mathrm{~mm})$ treated by means of RC procedures. Five databases were searched up to January 16, 2018. Random effects metaanalyses were conducted thoroughly.

Results: We included 48 RCTs in the SR. The results indicated a greater GR reduction for subepithelial connective tissue grafts (SCTG) + coronally advanced flap (CAF) compared to guided tissue regeneration with resorbable membranes (GTR rm) + CAF (mean difference [MD]: $-0.37 \mathrm{~mm}$ ). There was insufficient evidence of a difference in GR reduction between acellular dermal matrix grafts (ADMG) + CAF and SCTG + CAF or between enamel matrix derivative $(E M D)+C A F$ and SCTG + CAF. Greater gains in the keratinized tissue width (KTW) were found for SCTG + CAF when compared to EMD + CAF (MD: -1.06 mm), and SCTG + CAF when compared to GTR rm + CAF (MD: -1.77 mm). There was insufficient evidence of a difference in KTW gain between ADMG + CAF and SCTG + CAF.

Conclusions: SCTG, CAF alone or associated with another biomaterial may be for treating single or multiple GR. There is also some evidence suggesting that ADMG appear as the soft tissue substitute that may provide the most similar outcomes to those achieved by SCTG.

KEY WORDS (MESH verified): Gingival recession; therapy; surgery; tooth root; surgical flaps.

\section{INTRODUCTION}

This article is protected by copyright. All rights reserved. 
Different systematic reviews (SR) have been published focusing on the effect of root coverage $(R C)$ procedures on the treatment of single gingival recessions $(G R){ }^{2-7}$ These authors reported that different surgical techniques led to statistically significant improvements in recession depth (RD), clinical attachment level (CAL) and in the keratinized tissue width (KTW) (when indicated).$^{2-7}$ Also, it was recommended for clinical practice that when RC is indicated, subepithelial connective tissue grafts (SCTG), should be considered as the 'gold standard' procedure.$^{2-7}$ Moreover, the use of other biomaterials of allogenous (acellular dermal matrix graft $[\mathrm{ADMG}]^{8}$ ) or xenogenous (i.e. collagen membranes, ${ }^{9,10}$ enamel matrix derivative $[E M D]^{11}$ and collagen bilayer matrix graft $[\mathrm{XCM}]^{12}$ ) origin has been broadly studied since the late 1990 s to treat GR.

The previous version of this Cochrane Review ${ }^{13,14}$ endorsed these outcomes, and also emphasized the importance of SCTG in improving the KTW. Since its original publication in the Cochrane Database of Systemtatic Reviews in $2009^{13}$ and in the Journal of Periodontology in $2010,{ }^{14}$ the knowledge on RC procedures and materials have evolved and new randomized clinical trials (RCT) have been published so far. Thus, this updated version of the original Cochrane $\mathrm{SR}^{13,14}$ evaluated the efficacy of different $\mathrm{RC}$ procedures in the treatment of single and multiple GR.

\section{MATERIALS \& METHODS}

Detailed descriptions of the SR protocol (i.e., criteria for considering studies for the review, search methods for identification of studies, and data collection and analysis) used in this paper have been published previously. ${ }^{13,14}$ The following sections provide a brief description of the overall specific methodologic aspects of the 2018 version of the review. ${ }^{1}$

\section{Criteria for considering studies for this review}


Types of studies and participants: RCTs $\geq 6$ months' duration and reporting patientbased analysis. Studies were included if they reported the treatment of single or multiple Miller's ${ }^{15}$ Class I or II GR (RD $\left.\geq 3 \mathrm{~mm}\right)$, as well as at least 10 participants per group at final examination (with a follow-up $<5$ years).

Exclusion criteria: Studies including Miller's ${ }^{15}$ Class III and IV and restored root surfaces were not included.

Types of interventions: The interventions of interest were: a) free gingival grafts (FGG); b) laterally positioned flap (LPF); c) CAF; d) SCTG alone or in combination with LPF or CAF; and e) CAF in association with allograft (e.g., ADMG, others), GTR (with resorbabable [rs] or non-resorbable membranes [nrm]), EMD, XCM or other biomaterial. In addition, RCTs comparing variations of the same procedure (e.g. CAF with vertical incisions versus CAF without vertical incisions, etc) were also considered eligible for inclusion in the review.

Outcome measures: Primary outcome measures included aesthetic condition change (ACC) related to patient's opinion, complete root coverage (CRC) and RD change. Secondary outcome measures were as follows: CAL change, KTW change, mean root coverage (MRC), patients' preference for a specific RC procedure (in split-mouth trials), occurrence of adverse effects and/or postoperative complications. Outcome measures were separated into short-term (as evaluated 6 months to 12 months following interventions), medium-term (13 months to 59 months) or long-term ( $\geq 5$ years).

\section{Search methods for identification of studies (for details see supplementary Appendix 1 in online Journal of Periodontology).}

\section{Data collection and analysis}

Details regarding data collection until October 2008 were reported previously. ${ }^{13,14}$ Identification of studies conducted from November 2008 to January 16, 2018 were performed by two independent reviewers (LC and MASO). Agreement between review authors was assessed calculating Kappa scores. Disagreement between the review authors This article is protected by copyright. All rights reserved. 
was resolved by discussion with the inclusion of another review author (RR). Risk of bias (low, high, or unclear) of each included study was assessed using the Cochrane domainbased, two-part tool as described in the Cochrane Handbook for Systematic Reviews of Interventions. ${ }^{17}$

\section{Data synthesis}

Data were collated into evidence tables. Random-effects meta-analyses were used throughout. For continuous data, pooled outcomes were expressed as weighted mean differences (MD) with their associated 95\% confidence intervals (Cl). For dichotomous data, these were predominately pooled odds ratios $(\mathrm{OR})$ and associated $95 \% \mathrm{Cl}$. The analyses were conducted using the generic inverse variance statistical method where the MD or $\log [\mathrm{OR}]$ and standard error (SE) are entered for all studies. Becker-Balagtas method ${ }^{18}$ was used to calculate MD and log ORs, as indicated by Curtin et al. ${ }^{19}$ to accommodate data pooling from split-mouth and parallel-group studies in a single meta-analysis, and facilitate data synthesis. ${ }^{18}$ For split-mouth trials it was assumed a intracluster correlation co-efficient of 0.05 , while for parallel trials a co-efficient of zero for the calculation of SE. Statistical heterogeneity was assessed by calculation of the $Q$ statistic. Analyses were performed using RevMan software."

"Review Manager software, version 5.3; The Nordic Cochrane Centre, The Cochrane Collaboration, Copenhagen, Denmark

Variance imputation methods were conducted to estimate appropriate variance estimates in some split-mouth studies, where the appropriate standard deviation of the differences was not included in the trials. ${ }^{20}$ The significance of discrepancies in the estimates of the 
treatment effects from the different trials was assessed by means of Cochran's test for heterogeneity and the $\mathrm{I}^{2}$ statistic.

Presentation of main results: 'Summary of findings' tables for the main comparisons on single GR involving the "gold-standard" procedure (i.e., SCTG-based procedures versus other root coverage procedures) and the currently used alternative approaches (i.e., CAF, CAF + ADMG, CAF + EMD and CAF + XCM) ${ }^{5,21,22}$ were produced for the following outcomes: a) CRC; b) GR change; c) CAL change; and d) KTW change. GRADE methods, ${ }^{23}$ and the GRADEpro online tool were used for developing 'Summary of findings' tables (www.guidelinedevelopment.org). The quality of the body of evidence was assessed for each comparison and outcome by considering the overall risk of bias of the included studies, the directness of the evidence, the inconsistency of the results, the precision of the estimates, and the risk of publication bias. The quality of each body of evidence was categorised as high, moderate, low, or very low.

\section{RESULTS}

Results of the search and included studies

A total of 1714 records were retrieved from the searches (see supplementary Appendix 2 in online Journal of Periodontology). After the removal of duplicates, 724 records were screened for eligibility. 530 records were discarded, and the full-texts of 194 articles were assessed. From the 194 papers, 137 did not meet the criteria of eligibility and the reasons for exclusion were reported in the supplementary Appendix 3 in online Journal. Kappa scores for the searches conducted from November 2008 to January 2018 for title and/or abstract review, and full texts screening were 0.88 and 0.87 , respectively.

Forty-eight studies (reported in 57 papers $^{8-12,24-75}$ ) were included in the review, with 20 providing data for meta-analyses. Nine RCTs had their data reported in two articles each 
(i.e. according to the follow-up period or type of data (i.e. clinical or patient-reported outcomes). ${ }^{12,31,32,34,35,44,45,47-51,61-64,66,67}$ Consequently, the papers with a shorter follow-up period were included under the one study name (e.g. papers with the longer followup), $32,35,45,48,50,51,61,67$ while one article reporting patient-reported outcomes was included under the name of the clinical outcomes paper. ${ }^{64}$ Data on the type of study design, location and country of trial are described in Table 1. Five studies evaluated multiple $G R,{ }^{25,38,52,53,70}$ whereas the others single defects. Two studies ${ }^{32,59}$ evaluated exclusively outcomes of smokers (i.e. 10 or more cigarettes per day for more than 5 years). In addition, the majority of trials followed participants during a short-term period (6 months to 12 months). Only five publications with medium-term follow-up ${ }^{11,24,35,61,67}$ and five with long-term follow-up ${ }^{45,48,50,51,54}$ were included. In total, 1227 patients were treated and details on the different treatment modalities are depicted in Table 1.

\section{Risk of bias in included studies}

Only one study was considered to be at a low overall risk of bias (Figure 1) ${ }^{64}$ According to GRADE methods ${ }^{23}$ all evidence was considered to be of low to very low quality, mainly for imprecision and inconsistency (see supplementary Appendix 4 in online Journal of Periodontology).

\section{Effects of interventions}

ACC, GR change, CAL change and KTW change: ACC related to patient's opinion was reported in $10 \mathrm{RCTs}^{25,29,48,50,51,53,61,72,74,75}$ (Table 2) Given the heterogeneity of methods/criteria used to assess this outcome and types of procedures compared, formal pooling of data via meta-analysis was precluded. Of the 48 included trials, 18 evaluating single $\mathrm{GR}^{8-11,24,28,35,36,40,41,48,55,56,61,64,65,67,71}$ and two multiple $\mathrm{GR}^{52,70}$ were included into 11 sets 
of meta-analyses (Table 3). In addition, data from studies not included in meta-analyses are presented in supplementary Appendix 5 in online Journal.

Single GR: With respect to RD change, there was evidence of greater RD reduction for $\mathrm{EMD}+\mathrm{CAF}$ when compared to CAF alone (short/medium term; $\mathrm{P}=0.005, \mathrm{MD}: 0.32 \mathrm{~mm}$ ), for SCTG + CAF when compared to GTR rm + CAF (P=0.002, MD: $-0.37 \mathrm{~mm}$ ), for GTR rm + CAF associated with bone substitutes compared to GTR rm + CAF ( $P=0.02, \mathrm{MD}: 0.48$ $\mathrm{mm})$ and for $\mathrm{XCM}+\mathrm{CAF}$ compared to CAF alone ( $\mathrm{P}=0.006, \mathrm{MD}: 0.40 \mathrm{~mm})$. Regarding CAL change, there was evidence of greater reduction of CAL for EMD + CAF when compared to CAF alone (short/medium-term, $\mathrm{P}=0.009, \mathrm{MD}: 0.35 \mathrm{~mm}$ ), and for GTR $\mathrm{rm}+$ CAF compared to SCTG + CAF (P = 0.02, MD: of $0.35 \mathrm{~mm})$. For KTW change, there was evidence of greater gain in the KTW for EMD + CAF when compared to CAF alone (shortterm, $\mathrm{P}=0.001, \mathrm{MD}: 0.35 \mathrm{~mm}$; short $/$ medium term, $\mathrm{P}=0.0005, \mathrm{MD}: 0.40 \mathrm{~mm}$ ), for SCTG + CAF when compared to EMD + CAF $(P<0.00001, M D:-1.06 \mathrm{~mm})$, for SCTG + CAF when compared to GTR rm + CAF ( $<<0.0001$, mean difference $-1.77 \mathrm{~mm})$, for SCTG + CAF when compared to GTR rm + CAF associated with bone substitutes ( $P<0.00001$, MD: -2.38 $\mathrm{mm})$, and for $\mathrm{XCM}+\mathrm{CAF}$ when compared to CAF alone $(\mathrm{P}=0.03, \mathrm{MD}: 0.44 \mathrm{~mm})$. Multiple GR: There was evidence of greater reduction of CAL for SCTG + CAF compared to PRF + CAF $(P=0.02, M D:-0.37 \mathrm{~mm})$.

\section{CRC}

CRC was reported in 34 studies (Table 2) Among the included RCTs designed to evaluate single GR (excluding the data from Costa et al. ${ }^{31,32}$ and Reino et al. ${ }^{59}$ who included only heavy smokers), CRC varied from $0 \%{ }^{26}$ to $91.6 \%{ }^{8}$ for ADMG; $18.1 \%^{33}$ to $95.6 \%{ }^{12,51}$ for SCTG; $25 \%{ }^{24}$ to $89.5 \%{ }^{47,48}$ for EMD; $7.7 \%^{34,35}$ to $81.8 \%{ }^{73}$ for CAF; $33.3 \%{ }^{36}$ to $53.3 \%{ }^{55}$ for GTR rm; and $28 \%{ }^{10}$ to $41.6 \%{ }^{9}$ for GTR nrm. Also, OR analyses of six comparisons did not find statistical differences between procedures (Table 3). For XCM + CAF versus CAF, the 
combined therapy improved the achievement of sites displaying CRC compared to the use of CAF alone (OR of $4.73,95 \% \mathrm{Cl} 2.35$ to 9.50 ).

\section{MRC}

All included trials reported the MRC. Within studies evaluating single GR (excluding the data from two $\mathrm{RCT}^{31,32,59}$ who included heavy smokers), this outcome varied from $50 \%{ }^{41}$ to $96 \%{ }^{8}$ for ADMG, $64.7 \%{ }^{29}$ to $99.3 \%{ }^{12,51}$ for SCTG, $70.5 \%{ }^{39}$ to $95.1 \%{ }^{47,48}$ for EMD, $55.9 \%{ }^{34,35}$ to $95.4 \%{ }^{73}$ for CAF, $62.5 \%{ }^{46}$ to $73.7 \%{ }^{36}$ for GTR rm, $84.2 \%{ }^{61,62}$ to $89.9 \%{ }^{36}$ for GTR rm associated with bone substitutes, and $80.5 \%{ }^{10}$ to $82.4 \%{ }^{9}$ for GTR nrm (Table 2).

\section{Patients' preference for a specific RC procedure in split-mouth trials}

This update did not identify additional data to those already publish by the previous version of this SR. ${ }^{13,14}$ Details on this outcome are described in supplementary Appendix 6 in online Journal of Periodontology.

\section{Occurrence of adverse effects and/or postoperative complications}

Occurrence of adverse effects and/or postoperative complications during the postsurgical period was reported in 15 trials, ${ }^{12,28,36,39,40,42,45,47,49,52,66,71,72,74,75}$ but restricted to a limited number of patients/cases (see supplementary Appendix 7 in online Journal). Overall, the most common adverse outcomes were postsurgical pain/swelling within the first days after surgery, ADMG graft or membrane exposure and postoperative pain in donor site of SCTG.

\section{DISCUSSION}




\section{Summary of main results}

The main changes since the last version ${ }^{13,14}$ are reported in Figure 2. In spite of aesthetics being considered the primary goal of RC procedures, few studies had evaluated ACC related to patients' opinion. ${ }^{12,24,29,47-51,53,61,62,72,74,75}$ In these studies, the majority of the patients were satisfied with the final aesthetic result achieved (Table 2). Also, procedures that make a reduction in the operatory time possible, that eliminate the need for a second surgical site and that use smaller palatal grafts ${ }^{72,74}$ were better accepted by the patients. In terms of RD reduction, results from meta-analyses demonstrated evidence that at short-term: SCTG + CAF promoted additional gains to those achieved by GTR rm + CAF; XCM + CAF improved the gains obtained by CAF alone; EMD + CAF led to better stability of the gingival margin after treatment than CAF alone; and GTR rm + bone substitutes + CAF provided better outcomes than GTR rm + CAF (Table 3).

There was a marked variation between procedures in terms of the achievement of CRC at short-term (Table 2): $0 \%$ to $95.6 \%$. OR analyses on CRC did not reveal evidence of differences between procedures in none of the available comparisons, except for XCM + CAF versus CAF (i.e. the combined therapy promoted better outcomes). Additionally, some studies showed a decrease in the number of sites displaying CRC over time. ${ }^{12,33,34,47-51}$

With respect to secondary outcomes, four comparisons showed evidence that SCTG + CAF promoted additional gains in the KTW compared to EMD + CAF, GTR rm + CAF, or GTR rm + bone substitutes + CAF. Similarly, the use of EMD + CAF or XCM + CAF promoted additional gains in the KTW compared to the use of CAF alone (Table 3). Regarding CAL changes, there was evidence that SCTG + CAF promoted additional gains to those achieved by platelet-rich fibrin (PRF) + CAF, and that GTR rm + CAF promoted additional gains compared to SCTG + CAF. Also, there was a markedly variation in the amount of RC 
achieved. MRC varied from $44 \%$ to $99.3 \%$ (Table 2). Furthermore, data from some mediumand long-term trials ${ }^{12,33,34,47-51}$ showed that MRC decreased over time.

Patients' preference for a specific RC procedure followed the same pattern as ACC., ${ }^{9,71,72}$ Occurrence of an early discomfort with or without pain was related to donor sites of SCTG. ${ }^{47,48,52,71,72}$ This aspect may be related to the size of the graft obtained from the palate and the surgical approach used. ${ }^{72}$ Moreover, 'bigger grafts' were more associated to shrinkage of the covering flap with graft exposure when compared to 'small grafts'. ${ }^{72,74}$ In terms of flap preparation, the removal of the labial submucosal tissue, in the area of lower incisors, led to a reduction in the number of sites experiencing covering flap shrinkage than sites where the submucosal tissue was not removed. ${ }^{75}$

Although 48 RCTs were included in this Cochrane SR, it was difficult to combine data from these trials due to a great variability of comparisons between the various RC procedures and the inexistence of a unique gold standard control group in all studies. Consequently, only 20 trials were incorporated into meta-analyses ${ }^{8-12,24,28,34-36,40,41,47,48,52,55,56,61-67,70,71}$ in 11 different group comparisons (Table 3). Few studies reported a follow-up period superior to 12 months. ${ }^{12,24,34,35,44,45,47-51,54,61,62,66,67}$ In six of these studies a chronological evaluation of the results evidenced loss in the amount of RC obtained (e.g. MRC and CRC) between the 6 months to 12 months period of evaluation ${ }^{11,34,35,66,67}$ and between the first year and 5-and 10-year follow-ups. ${ }^{12,47-51}$ This assumption was evidenced by the findings of pooled estimates on EMD + CAF versus CAF (Table 3). Two trials ${ }^{31,32,59}$ evidenced the detrimental impact of smoking on root coverage outcomes (i.e. MRC and CRC decrease) within patients who smoke $\geq 10$ cigarettes per day for more than 5 years.

Overall, both the individual studies' outcomes (i.e. within-group comparisons reported by each individual trial) and findings of pooled estimates clearly demonstrated that all RC procedures included in this Cochrane Review promoted reduction in the extent of GR and 
concomitant gain in the CAL for both single and multiple GR. Likewise, it was evidenced that KTW augmentation of these sites was associated to the use of SCTG or allogenous (ADMG)/xenogenous (XCM) soft tissue substitutes.

\section{Quality of the evidence}

Only one study was considered to be at a low overall risk of bias. GRADE methods ${ }^{23}$ were used to assess the quality of the body of evidence of our main comparisons and our assessment is presented in the supplementary Appendix 4 in online Journal of Periodontology with all evidence considered to be of low to very low quality, mainly for imprecision and inconsistency.

\section{Potential biases in the review process}

In this review, only defects $\geq 3 \mathrm{~mm}$ were included in order to minimize heterogeneity between the trials. However, this inclusion criterion could have eliminated data from studies that could be incorporated into meta-analyses.

\section{Agreements and disagreements with other studies or reviews}

Important aspects already described in both the previous ${ }^{13,14}$ and current versions of this Cochrane SR are depicted in supplementary Appendix 8 in online Journal. The current version of this SR evidenced that both patients and clinicians seem to agree that, in terms of aesthetic perception, CRC is perceived as the primary 'successful outcome' of a RC procedure. ${ }^{76}$ However, it is important to highlight that patients' perception of buccal recessions is not high (approximately half of the patients with one gingival recession do not perceive them), as well as that the majority of those defects do not lead to functional or aesthetic concerns. ${ }^{77}$ 
It has been demonstrated by an individual patient data meta-analysis of 602 Miller Class I and II recession defects ${ }^{4}$ that the greater the baseline $\mathrm{RD}$, the smaller the chance of $\mathrm{CRC}$. It should also be noted that the inclusion of studies with recession defects $\geq 4 \mathrm{~mm}$ tends to show greater differences between baseline and follow-up means (i.e. outcome change), a factor that may influence the calculation of meta-analyses. ${ }^{4,13,14}$ Another couple of studies ${ }^{78,79}$ demonstrated that sites in which the gingival margin was sutured at the level of the cementoenamel junction the achievement of CRC was inferior to those sites where a trapezoidal flap was sutured coronal (approximately $1 \mathrm{~mm}$ to $2 \mathrm{~mm}$ ) (i.e. the more apical the gingival margin after surgery, the smaller the chance of $\mathrm{CRC}$ ). Moreover, other anatomic aspects related to the interproximal dental papillae were already described previously ${ }^{13,14}$ (see supplementary Appendix 8 in online Journal of Periodontology). Consequently, all these factors make comparisons and combination of data from different trials a critical issue.

It has been shown that smoking can affect the results obtained by RC procedures. ${ }^{5}$ Two $\mathrm{RCTs}^{31,32,59}$ evaluated only patients who smoked $\geq 10$ cigarettes per day for at least 5 years, and their results showed that heavy smokers may be benefited by RC therapy, as well. However, MRC and CRC were clearly inferior to the outcomes achieved by trials evaluating non-smokers (Table 2). Eight trials ${ }^{29,30,40,12,51,73-75}$ reported the inclusion of smokers who smoked less than 10 cigarettes per day. None of them performed comparisons between smokers and non-smokers. Zucchelli et al. ${ }^{10}$ commented only that patients who smoke more than 10 cigarettes a day presented the worst percentage of RC. This is in line with included RCTs on smokers ${ }^{31,32,59}$ and the data from other studies that have assessed the amount of RC obtained by smokers and non-smokers through CAF and SCTG. ${ }^{5,3,14}$

The present version of this Cochrane Review is completely in line with data from the recent American Academy of Periodontology Regeneration Workshop $\mathrm{SR}^{5}$ that concluded that: 1) "all RC procedures can provide significant reduction in RD and CAL gain without alteration of 
probing depth for Miller Class I and II single GR, but multiple GR seems to be benefit as well despite the reduced quantity of information available;" 2) "SCTG-based procedures provided the best outcomes for clinical practice because of their superior percentages of MRC and CRC and the significant increase of KTW when compared with most of the other procedures" (as reported by the individual studies' outcomes, Table 2); 3) "the use of CAF with ADMG, EMD, and XCM also provided gains, many of them similar to SCTG-based procedures, and thus these may be considered as adequate substitute treatment approaches"; and 4) "smoking may decrease the expected results".

It is also important to highlight that recent evidence from three long-term non-randomized studies, that followed patients for at least 20 years, found that GR relapse appears to be associated to sites lacking an attached $\mathrm{KT}$ band of at least $2 \mathrm{~mm} \cdot{ }^{80-82}$ Similarly, a recent $\mathrm{SR}^{83}$ evaluating the long-term outcomes of untreated buccal GR (in terms of associated reported aesthetic and functional alterations and factors influencing the progression/worsening of dental and periodontal tissue conditions) found that: a) untreated GR in individuals with good oral hygiene are highly likely to experience RD increase during long-term follow-up ( $78 \%$ of the defects displayed clinical worsening); and b) the presence of KTW and/or greater KTW decrease the chance of RD increase or the development of new recessions. Nonetheless, individual data from some of the studies included in the present SR suggest that SCTG promoted better stability of the gingival margin/some degree of creeping attachment over time, compared to other surgical approaches. ${ }^{12,24,40,51,70}$

\section{CONCLUSIONS}

- All the analyzed RC procedures led to RD reduction and CAL gain and thus can be used in clinical practice. However, there was a great variability in the percentages of CRC and MRC.

- The available evidence base indicates that the most suitable options for RC of single GR, in terms of clinical outcomes and cost-to-benefit ratio, are: (1) SCTG plus CAF; (2) ADMG 
plus CAF; (3) EMD + CAF; (4) XCM + CAF; and (5) CAF alone. Despite of the restricted number of studies on multiple GR included in this SR, this 'hierarchy criterion' may be applied for the treatment of such defects, as well.

- GTR could be used to treat single GR, but most the information on these procedures were obtained from studies published up to the early $2000^{\prime} 0$.

- Individual studies' outcomes and the available pooled estimates suggest that SCTG plus CAF may be considered as 'gold standard' procedure for the treatment of single and multiple GR. Moreover, evidence suggests that SCTG promoted better stability of the gingival margin/some degree of creeping attachment over time, compared to other surgical approaches.

- ADMG (primarily) and XCM (secondly) may be considered as alternative soft tissue grafting materials.

- Outcome measures of the evaluated surgical techniques were not improved by the use of root modification agents or the type of mechanical root scaling during surgery.

- The incidence of adverse effects, such as discomfort with or without pain, was mainly related to donor sites of SCTG. However, these conditions occurred mainly within the first week after surgery and did not influence on RC outcomes.

\section{Implications for research}

- Limited data exist on ACC related to patient's opinion, thus further RCTs are still required to evaluate this primary outcome variable. The use of the VAS (or other 'standardized scales') will allow more precise evaluations of patient-based outcomes.

- Future split-mouth trials should focus on patients' preference for a specific RC procedure.

- The inclusion of baseline and final individual defect measurements will allow more precise evaluations, as well as subgroup evaluations (e.g. patients presenting similar defects) and future comparisons via meta-analyses. These outcome measures should include GR depth and width, CAL, KTW and thickness, and root surface conditions (i.e. presence of caries, abrasions or restorations). Also, in order to draw more robust conclusions about treatment of 
sites lacking attached gingiva: a) the number of Miller Class I and II should be balanced and equally distributed in the study groups (i.e., test and control); and b) the differences in response to treatment between these sites should be considered.

- Comparisons between different operators (i.e. with respect to the degree of operator's experience) remain necessary to evaluate differences in the expected outcome measures.

- Considering the proposed inclusion criteria, no data were available for LPF and there is limited information for FGG and platelet-rich fibrin. These procedures might be evaluated by future research.

\section{ACKNOWLEDGEMENTS}

The review authors would like to acknowledge Anne Littlewood for her assistance on the search strategy section and Helen Worthington, Ian Needleman, Luisa Fernandez Mauleffinch and Marco Esposito from Cochrane Oral Health for their help with the preparation of the protocol and full text of the review. We would like to thank Professor Kevin Seymour from Division of Dentistry, School of Medical Sciences, Faculty of Biology, Medicine and Health, the University of Manchester for providing comments on this update.

\section{REFERENCES}

1. Chambrone L, Salinas Ortega MA, Sukekava F, et al. Root coverage procedures for treating localised and multiple recession-type defects. Cochrane Database Syst Rev 2018; 10: CD007161.

2. Chambrone L, Chambrone D, Pustiglioni FE, Chambrone LA, Lima LA. Can subepithelial connective tissue grafts be considered the gold standard procedure in the treatment of Miller Class I and II recession-type defects?. J Dent 2008;36:659-671.

3. Chambrone L, Faggion CM Jr, Pannuti CM, Chambrone LA. Evidence-based periodontal plastic surgery: an assessment of quality of systematic reviews in the treatment of recession-type defects. J Clin Periodontology 2010;37:1110-1118.

4. Chambrone L, Pannuti CM, Tu YK, Chambrone LA. Evidence-based periodontal plastic surgery. II. An individual data meta-analysis for evaluating factors in achieving complete root coverage. Journal of Periodontology 2012;83:477-490. 
5. Chambrone L, Tatakis DN. Periodontal soft tissue root coverage procedures: a systematic review from the AAP Regeneration Workshop. Journal of Periodontology 2015;86 (2 Suppl):S8-51.

6. Buti J, Baccini M, Nieri M, La Marca M, Pini-Prato GP. Bayesian network meta-analysis of root coverage procedures ranking efficacy and identification of best treatment. $J$ Clin Periodontol 2013;40:372-386.

7. Pini Prato G, Nieri M, Pagliaro U, et al. Surgical treatment of single gingival recessions: clinical guidelines. Eur J Oral Implantol 2014;7:9-43.

8. Woodyard JG, Greenwell H, Hill M, Drisko C, lasella JM, Scheetz J. The clinical effect of acellular dermal matrix on gingival thickness and root coverage compared to coronally positioned flap alone. J Periodontol 2004;75:44-56.

9. Roccuzzo M, Lungo M, Corrente G, Gandolfo S. Comparative study of a bioresorbable and a non-resorbable membrane in the treatment of human buccal gingival recessions. J Periodontol 1996;67:7-14.

10. Zucchelli G, Clauser C, De Sanctis M, Calandriello M. Mucogingival versus guided tissue regeneration procedures in the treatment of deep recession type defects. $J$ Periodontol 1998;69:138-145.

11. Del Pizzo M, Zucchelli G, Modica F, Villa R, Debernardi C. Coronally advanced flap with or without enamel matrix derivative for root coverage: a 2-year study. J Clin Periodontol 2005;32:1181-1187.

12. McGuire MK, Scheyer ET. Xenogeneic collagen matrix with coronally advanced flap compared to connective tissue with coronally advanced flap for the treatment of dehiscence-type recession defects. J Periodontol 2010;81:1108-1117.

13. Chambrone L, Sukekava F, Araújo MG, Pustiglioni FE, Chambrone LA, Lima LA. Root coverage procedures for the treatment of localised recession-type defects. Cochrane Database Syst Rev 2009; 2: CD007161

14. Chambrone L, Sukekava F, Araújo MG, Pustiglioni FE, Chambrone LA, Lima LA. Root-coverage procedures for the treatment of localized recession-type defects: a Cochrane systematic review. J Periodontol 2010;81:452-478.

15. Miller PD Jr. A classification of marginal tissue recession. Int J Periodontics Restorative Dent 1985;5(2):8-13.

16. Lefebvre C, Manheimer E, Glanville J. Chapter 6: Searching for studies. In: Higgins JP, Green S, editor(s). Cochrane Handbook for Systematic Reviews of Interventions Version 5.1.0 (updated March 2011). The Cochrane Collaboration, 2011. Available from http://handbook-51.cochrane.org/.

This article is protected by copyright. All rights reserved. 
17. Higgins JPT, Green S, editor(s). Cochrane Handbook for Systematic Reviews of Interventions Version 5.1.0 (updated March 2011). The Cochrane Collaboration, 2011. Available from http://handbook-5-1.cochrane.org/.

18. Stedman MR, Curtin F, Elbourne DR, Kesselheim AS, Brookhart MA. Meta-analyses involving cross-over trials: methodological issues. International J Epidemiol 2011;40:1732-1734.

19. Curtin F, Elbourne D, Altman DG. Meta-analysis combining parallel and cross-over clinical trials. II: Binary outcomes. Stat Med 2002;21:2145-2159.

20. Follmann D, Elliott $P$, Suh I, Cutler J. Variance imputation for overviews of clinical trials with continuous response. J Clin Epidemiol 1992;45:769-773.

21. Tatakis DN, Chambrone L, Allen EP, et al. Periodontal soft tissue root coverage procedures: a consensus report from the AAP Regeneration Workshop. J Periodontol 2015;86 (2 Suppl):S5255.

22. Richardson $C R$, Allen EP, Chambrone $L$, et al. Periodontal soft tissue root coverage procedures: practical applications from the AAP Regeneration Workshop. Clin Adv Periodontics 2015;5:2-10.

23. Atkins D, Best D, Briss PA, et al; GRADE Working Group. Grading quality of evidence and strength of recommendations. BMJ 2004;328:1490-1494.

24. Abolfazli N, Saleh-Saber F, Eskandari A, Lafzi A. A comparative study of the long term results of root coverage with connective tissue graft or enamel matrix protein: 24-month results. Med Oral, Patol Oral, Cir Bucal 2009;14:E304-309.

25. Ahmedbeyli C, Ipci SD, Cakar G, Kuru BE, Y Imaz S. Clinical evaluation of coronally advanced flap with or without acellular dermal matrix graft on complete defect coverage for the treatment of multiple gingival recessions with thin tissue biotype. J Clin Periodontol 2014;41:303-310.

26. Ayub LG, Ramos UD, Reino DM, et al. Randomized comparative clinical study of two surgical procedures to improve root coverage with the acellular dermal matrix graft. $J$ Clin Periodontol 2012;39:871-878.

27. Babu HM, Gujjari SK, Prasad D, Sehgal PK, Srinivasan A. Comparative evaluation of a bioabsorbable collagen membrane and connective tissue graft in the treatment of localized gingival recession: a clinical study. J Indian Soc Periodontol 2011;15:353-358.

28. Barros RRM, Macedo GO, de Queiroz AC, Novaes Jr AB. A modified surgical flap for root coverage in association with grafting materials. J Esthetic Restorative Dent 2015;27:84-91.

29. Bouchard P, Etienne D, Ouhayoun JP, Nilveus R. Subepithelial connective tissue grafts in the treatment of gingival recessions. A comparative study of 2 procedures. $J$ Periodontol 1994;65:929-936. 
30. Bouchard P, Nilveus R, Etienne D. Clinical evaluation of tetracycline $\mathrm{HCl}$ conditioning in the treatment of gingival recessions. A comparative study. J Periodontol 1997;68:262-269.

31. Alves LB, Costa PP, de Souza SLS, et al. Acellular dermal matrix graft with or without enamel matrix derivative for root coverage in smokers: a randomised clinical study. $J$ Clin Periodontol 2012;39:393-399.

32. Costa PP, Alves LB, Souza SL, et al. Root coverage in smokers with acellular dermal matrix graft and enamel matrix derivative: a 12-month randomized clinical trial. Int J Periodontics Restorative Dent 2016;36:525-531.

33. da Silva RC, Joly JC, de Lima AF, Tatakis DN. Root coverage using the coronally positioned flap with or without a subepithelial connective tissue graft. J Periodontol 2004;75:413-419.

34. de Queiroz Cortes A, Martins AG, Nociti FH Jr, Sallum AW, Casati MZ, Sallum EA. Coronally positioned flap with or without acellular dermal matrix graft in the treatment of Class I gingival recessions: a randomized controlled clinical study. J Periodontol 2004;75:1137-1144.

35. de Queiroz Cortes A, Sallum AW, Casati MZ, Nociti FH Jr, Sallum EA. A two-year prospective study of coronally positioned flap with or without acellular dermal matrix graft. J Clin Periodontol 2006;33:683-689.

36. Dodge JR, Greenwell H, Drisko C, Wittwer JW, Yancey J, Rebitski G. Improved bone regeneration and root coverage using a resorbable membrane with physically assisted cell migration and DFDBA. Int J Periodontics Restorative Dent 2000;20:398-411.

37. Henderson RD, Greenwell H, Drisko C, et al. Predictable multiple site root coverage using an acellular dermal matrix allograft. $J$ Periodontol 2001;72:571-582.

38. Jaiswal GR, Kumar R, Khatri PM, Jaiswal SG, Bhongade ML. The effectiveness of enamel matrix protein (Emdogain) in combination with coronally advanced flap in the treatment of multiple marginal tissue recession: a clinical study. J Indian Soc Periodontol 2012; 16:224-230.

39. Jankovic S, Aleksic Z, Milinkovic I, Dimitrijevic B. The coronally advanced flap in combination with platelet rich fibrin (PRF) and enamel matrix derivative in the treatment of gingival recession: a comparative study. Eur J Esthet Dent 2010;5:260-273.

40. Jepsen K, Jepsen S, Zucchelli G, et al. Treatment of gingival recession defects with a coronally advanced flap and a xenogeneic collagen matrix: a multicenter randomized clinical trial. $J$ Clin Periodontol 2013;40:82-89.

41. Joly JC, Carvalho AM, da Silva RC, Ciotti DL, Cury PR. Root coverage in isolated gingival recessions using autograft versus allograft: a pilot study. J Periodontol 2007;78:1017-1022.

42. Keceli HG, Sengun D, Berberoglu A, Karabulut E. Use of platelet gel with connective tissue grafts for root coverage: a randomized-controlled trial. J Clin Periodontol 2008;35:255-262.

This article is protected by copyright. All rights reserved. 
43. Keceli HG, Kamak G, Erdemir EO, Evginer MS, Dolgun A. The adjunctive effect of platelet-rich fibrin to connective tissue graft in the treatment of buccal recession defects: results of a randomized, parallel-group controlled trial. J Periodontol 2015;86:1221-1230.

44. Amarante ES, Leknes KN, Skavland J, Lie T. Coronally positioned flap procedures with or without a bioabsorbable membrane in the treatment of human gingival recession. $J$ Periodontol 2000;71:989-998.

45. Leknes KN, Amarante ES, Price DE, Boe OE, Skavland RJ, Lie T. Coronally positioned flap procedures with or without a biodegradable membrane in the treatment of human gingival recession. A 6-year follow-up study. J Clin Periodontol 2005;32:518-529.

46. Matarasso S, Cafiero C, Coraggio F, Vaia E, de Paoli S. Guided tissue regeneration versus coronally repositioned flap in the treatment of recession with double papillae. Int $\mathrm{J}$ Periodontics Restorative Dent 1998;18:444-453.

47. McGuire MK, Nunn M. Evaluation of human recession defects treated with coronally advanced flaps and either enamel matrix derivative or connective tissue. Part 1: comparison of clinical parameters. J Periodontol 2003;74:1110-1125.

48. McGuire MK, Scheyer ET, NunnM. Evaluation of human recession defects treated with coronally advanced flaps and either enamel matrix derivative or connective tissue: comparison of clinical parameters at 10 years. $J$ Periodontol 2012;83:1353-1362.

49. McGuire MK, Scheyer ET, Schupbach P. Growth factor mediated treatment of recession defects: a randomized controlled trial and histologic and microcomputed tomography examination. $J$ Periodontol 2009; 80:550-564.

50. McGuire MK, Scheyer ET, Snyder MB. Evaluation of recession defects treated with coronally advanced flaps and either recombinant human platelet-derived growth factor-BB plus b-tricalcium phosphate or connective tissue: comparison of clinical parameters at 5 years. J Periodontol 2014;85:1361-1370.

51. McGuire MK, Scheyer ET. Long-term results comparing xenogeneic collagen matrix and autogenous connective tissue grafts with coronally advanced flaps for treatment of dehiscencetype recession defects. J Periodontol 2016;87:221-227.

52. Öncü $E$. The use of platelet-rich fibrin versus subepithelial connective tissue graft in treatment of multiple gingival recessions: a randomized clinical trial. Int J Periodontics Restorative Dent 2017;37:265-271.

53. Ozenci I, Ipci SD, Cakar G, Yilmaz S. Tunnel technique versus coronally advanced flap with acellular dermal matrix graft in the treatment of multiple gingival recessions. $J$ Clin Periodontol 2015;42:1135-1142.

54. Paolantonio M, di Murro C, Cattabriga A, Cattabriga M. Subpedicle connective tissue graft versus free gingival graft in the coverage of exposed root surfaces. A 5-year clinical study. J Clin Periodontol 1997;24:51-56.

This article is protected by copyright. All rights reserved. 
55. Paolantonio M. Treatment of gingival recessions by combined periodontal regenerative technique, guided tissue regeneration, and subpedicle connective tissue graft. A comparative clinical study. J Periodontol 2002;73:53-62.

56. Paolantonio M, Dolci M, Esposito $\mathrm{P}$, et al. Subpedicle acellular dermal matrix graft and autogenous connective tissue graft in the treatment of gingival recessions: a comparative 1-year clinical study. J Periodontol 2002;73:1299-1307.

57. Pendor S, Baliga V, Bhongade ML, Turakia V, Shori T. A comparison between connective tissue grafts combined with either double pedicle grafts or coronally positioned pedicle grafts: a clinical study. J Indian Soc Periodontol 2014;18:326-330.

58. Rasperini G, Roccuzzo M, Francetti L, Acunzo R, Consonni D, Silvestri M. Subepithelial connective tissue graft for treatment of gingival recessions with and without enamel matrix derivative: a multicenter, randomized controlled clinical trial. Int $J$ Periodontics Restorative Dent 2011;31:133-139.

59. Reino DM, Novaes Jr AB, Maia LP, et al. Treatment of gingival recessions in heavy smokers using two surgical techniques: a controlled clinical trial. Braz Dent J 2012;23:59-67.

60. Reino DM, Maia LP, Fernandes PG, et al. A randomized comparative study of two techniques to optimize the root coverage using a porcine collagen matrix. Braz Dent J 2015;26:445-450.

61. Rosetti EP, Marcantonio E Jr, Zuza EP, Marcantonio RAC. Root coverage stability of the subepithelial connective tissue graft and guided tissue regeneration: a 30-month follow-up clinical trial. J Dent 2013;41:114-120.

62. Rosetti EP, Marcantonio RA, Rossa C Jr, Chaves ES, Goissis G, Marcantonio E Jr. Treatment of gingival recession: comparative study between subepithelial connective tissue graft and guided tissue regeneration. $J$ Periodontol 2000;71:1441-1447.

63. Rocha Dos Santos M, Sangiorgio JPM, Neves FLDS, et al. Xenogenous collagen matrix and/or enamel matrix derivative for treatment of localized gingival recessions: a randomized clinical trial. Part II: patient-reported outcomes. J Periodontol 2017;88:1319-1328.

64. Sangiorgio JPM, Neves FLDS, Rocha Dos Santos M, et al. Xenogenous collagen matrix and/or enamel matrix derivative for treatment of localized gingival recessions: a randomized clinical trial. Part I: clinical outcomes. J Periodontol 2017;88:1309-1318.

65. Shori T, Kolte A, Kher V, Dharamthok S, Shrirao T. A comparative evaluation of the effectiveness of subpedicle acellular dermal matrix allograft with subepithelial connective tissue graft in the treatment of isolated marginal tissue recession: a clinical study. J Indian Soc Periodontol 2013;17:78-81.

66. Hagewald S, Spahr A, Rompola E, Haller B, Heijl L, Bernimoulin JP. Comparative study of Emdogain and coronally advanced flap technique in the treatment of human gingival recessions. A prospective controlled clinical study. J Clin Periodontol 2002;29:35-41. 
67. Spahr A, Haegewald S, Tsoulfidou F, et al. Coverage of Miller class I and II recession defects using enamel matrix proteins versus coronally advanced flap technique: a 2-year report. $J$ Periodontol 2005;76:1871-1880.

68. Tozum TF, Keceli HG, Guncu GN, Hatipoglu H, Sengun D. Treatment of gingival recession: comparison of two techniques of subepithelial connective tissue graft. $J$ Periodontol 2005;76:1842-1848.

69. Trombelli L, Scabbia A, Wikesjö UM, Calura G. Fibrin glue application in conjunction with tetracycline root conditioning and coronally positioned flap procedure in the treatment of human gingival recession defects. J Clin Periodontol 1996;23:861-867.

70. Tunali M, Ozdemir H, Arabaci T, Pikdoken ML. Clinical evaluation of autologous platelet-rich fibrin in the treatment of multiple adjacent gingival recession defects: a 12-month study. Intl $J$ Periodontics Restorative Dent 2015;35:105-114.

71. Wang HL, Bunyaratavej P, Labadie M, Shyr Y, MacNeil RL. Comparison of 2 clinical techniques for treatment of gingival recession. J Periodontol 2001;72:1301-1311.

72. Zucchelli G, Amore C, Sforzal NM, Montebugnoli L, De Sanctis M. Bilaminar techniques for the treatment of recession-type defects. A comparative clinical study. J Clin Periodontol 2003;30:862-870.

73. Zucchelli G, Mounssif I, Stefanini M, Mele M, Montebugnoli L, Sforza NM. Hand and ultrasonic instrumentation in combination with root-coverage surgery: a comparative controlled randomized clinical trial. J Periodontol 2009;80:577-585.

74. Zucchelli G, Mounssif I, Mazzotti C, et al. Does the dimension of the graft influence patient morbidity and root coverage outcomes? A randomized controlled clinical trial. J Clin Periodontol 2014;41:708-716.

75. Zucchelli G, Marzadori M, Mounssif I, Mazzotti C, Stefanini M. Coronally advanced flap + connective tissue graft techniques for the treatment of deep gingival recession in the lower incisors. A controlled randomized clinical trial. J Clin Periodontol 2014;41:806-813.

76. Rotundo R, Nieri M, Mori M, Clauser C, Pini Prato G. Aesthetic perception after root coverage procedure. J Clin Periodontol 2008;35:705-712.

77. Nieri M, Pini Prato GP, Giani M, Magnani N, Pagliaro U, Rotundo R. Patient perceptions of buccal gingival recessions and requests for treatment. J Clin Periodontol 2013;40:707-712.

78. Nieri M, Rotundo R, Franceschi D, Cairo F, Cortellini P, Pini Prato G. Factors affecting the outcome of the coronally advanced flap procedure: a Bayesian network analysis. J Periodontol 2009;80:405-410.

79. Pini Prato GP, Baldi C, Nieri M, et al. Coronally advanced flap: the post-surgical position of the gingival margin is an important factor for achieving complete root coverage. $J$ Periodontol 2005;76:713-722.

This article is protected by copyright. All rights reserved. 
80. Agudio G, Chambrone L, Pini Prato G. Biologic remodeling of periodontal dimensions of areas treated with gingival augmentation procedure: a 25-year follow-up observation. J Periodontol 2017;88:634-642.

81. Pini Prato G, Magnani C, Chambrone L. Long-term evaluation (20 years) of the outcomes of coronally advanced flap in the treatment of single recession-type defects. $J$ Periodontol 2018; 89:265-274.

82. Pini Prato GP, Franceschi D, Cortellini P, Chambrone L. Long-term evaluation (20 years) of the outcomes of subepithelial connective tissue graft plus coronally advanced flap in the treatment of maxillary single recession-type defects. J Periodontol 2018;89:1290-1299.

83. Chambrone L, Tatakis DN. Long-term outcomes of untreated buccal gingival recessions: a systematic review and meta-analysis. J Periodontol 2016;87:796-808.

Figure legends.

Figure 1 - Risk of bias summary: review authors' judgements about each risk of bias item for each included study.

Figure 2 - 'What's new' table - changes since the last version.

\section{Table 1 - Characteristics of included studies}




\begin{tabular}{|c|c|c|c|c|c|}
\hline Study & $\begin{array}{l}\text { Method } \\
\mathrm{s}\end{array}$ & $\begin{array}{l}\text { Participant } \\
\text { s }\end{array}$ & Interventions & Outcomes & Notes \\
\hline $\begin{array}{l}\text { Abolfazli et } \\
\text { al. }^{24}\end{array}$ & $\begin{array}{l}\text { RCT, } \\
\text { split- } \\
\text { mouth } \\
\text { design, } \\
2 \\
\text { treatme } \\
\text { nt } \\
\text { groups, } \\
24 \\
\text { months' } \\
\text { duration }\end{array}$ & $\begin{array}{l}12 \\
\text { individuals, } \\
8 \text { females, } \\
\text { aged } 28 \text { to } \\
51 \text { years, } \\
\text { with } 2 \\
\text { bilateral } \\
\text { Miller Class } \\
\text { I buccal } \\
\text { gingival } \\
\text { recessions } \\
\text { of at least } 3 \\
\mathrm{~mm}\end{array}$ & $\begin{array}{l}\text { 1. } E M D+C A F \\
\text { 2. SCTG + CAF }\end{array}$ & $\begin{array}{l}\operatorname{GRC}^{*}(2), \\
\operatorname{CALC}^{*}(2), \\
\operatorname{KTC}^{*}(2), \\
\operatorname{SCRC}^{\prime} \\
\operatorname{PCRC}^{*}(2), \\
\operatorname{MRC}^{*}(2) \\
\text { (Manual } \\
\text { probe) }\end{array}$ & $\begin{array}{l}\text { Practice-based } \\
\text { (Iran) }\end{array}$ \\
\hline $\begin{array}{l}\text { Ahmedbeyli } \\
\text { et al. }{ }^{25}\end{array}$ & $\begin{array}{l}\text { RCT, } \\
\text { parallel } \\
\text { design, } \\
2 \\
\text { treatme } \\
\text { nt } \\
\text { groups, } \\
12 \\
\text { months' } \\
\text { duration }\end{array}$ & $\begin{array}{l}24 \\
\text { individuals, } \\
12 \text { females, } \\
\text { aged } 22 \text { to } \\
40 \text { years, } \\
\text { with Miller } \\
\text { Class I } \\
\text { multiple } \\
\text { buccal } \\
\text { gingival } \\
\text { recessions } \\
\text { of at least } 3 \\
\text { mm }\end{array}$ & $\begin{array}{l}\text { 1. } A D M G+C A F \\
\text { 2. } C A F\end{array}$ & $\begin{array}{l}\text { ACC, } \\
\text { GRC }^{*}(1), \\
\text { CALC }^{*}(1) \\
\text { KTC }^{*}(1), \\
\text { SCRC, } \\
\text { PCRC, MRC } \\
\text { (Manual } \\
\text { probe) }\end{array}$ & $\begin{array}{l}\text { University/hospi } \\
\text { tal-based } \\
\text { (Turkey) }\end{array}$ \\
\hline Ayub et al. ${ }^{26}$ & $\begin{array}{l}\text { RCT, } \\
\text { split- } \\
\text { mouth } \\
\text { design, } \\
2 \\
\text { treatme } \\
\text { nt } \\
\text { groups, } \\
6 \\
\text { months' } \\
\text { duration }\end{array}$ & $\begin{array}{l}15 \\
\text { individuals, } \\
\text { number of } \\
\text { females not } \\
\text { reported, } \\
\text { aged } 20 \text { to } \\
56 \text { years, } \\
\text { with } 2 \\
\text { bilateral } \\
\text { Miller Class } \\
\text { I or II buccal } \\
\text { gingival } \\
\text { recessions } \\
\text { of at least } 3 \\
\text { mm }\end{array}$ & $\begin{array}{l}\text { 1. ADMG (positioned } 1 \mathrm{~mm} \text { apical to } \\
\text { the cemento-enamel junction) }+ \\
\text { CAF (extended flap) } \\
\text { 2. ADMG + CAF (extended flap) }\end{array}$ & $\begin{array}{l}\text { GRC*(1), } \\
\text { CALC }^{*}(1), \\
\text { KTC, SCRC, } \\
\text { PCRC, MRC } \\
\text { (Automated } \\
\text { controlled } \\
\text { force probe } \\
\text { and manual } \\
\text { probe) }\end{array}$ & $\begin{array}{l}\text { University/hospi } \\
\text { tal-based } \\
\text { (Brazil) and } \\
\text { supported by } \\
\text { the State of São } \\
\text { Paulo Research } \\
\text { Foundation } \\
\text { and } \\
\text { BioHorizons Inc }\end{array}$ \\
\hline $\begin{array}{l}\text { Babu et } \\
\text { al. }^{27}\end{array}$ & $\begin{array}{l}\text { RCT, } \\
\text { split- } \\
\text { mouth } \\
\text { design, } \\
2 \\
\text { treatme } \\
\text { nt } \\
\text { groups, } \\
6 \\
\text { months' } \\
\text { duration }\end{array}$ & $\begin{array}{l}10 \\
\text { individuals, } \\
\text { number of } \\
\text { females not } \\
\text { reported, } \\
\text { age not } \\
\text { reported, } \\
\text { with } 2 \text { Miller } \\
\text { Class I or II } \\
\text { buccal } \\
\text { gingival } \\
\text { recessions } \\
\text { of at least } 3 \\
\text { mm }\end{array}$ & $\begin{array}{l}\text { 1. GTR + CAF (collagen membrane } \\
\text { - Bioproducts Lab) } \\
\text { 2. SCTG + CAF }\end{array}$ & $\begin{array}{l}\text { GRC, CALC, } \\
\text { KTC, MRC } \\
\text { (Manual } \\
\text { probe) }\end{array}$ & $\begin{array}{l}\text { University/hospi } \\
\text { tal-based (India) }\end{array}$ \\
\hline $\begin{array}{l}\text { Barros et } \\
\text { al. }^{28}\end{array}$ & $\begin{array}{l}\text { RCT, } \\
\text { split- } \\
\text { mouth } \\
\text { design, } \\
2 \\
\text { treatme } \\
\text { nt } \\
\text { groups, }\end{array}$ & $\begin{array}{l}15 \\
\text { individuals, } \\
10 \text { females, } \\
\text { aged } 23 \text { to } \\
54 \text { years, } \\
\text { with } 2 \\
\text { bilateral } \\
\text { Miller Class }\end{array}$ & $\begin{array}{l}\text { 1. ADMG + CAF (extended flap) } \\
\text { 2. SCTG + CAF (extended flap) }\end{array}$ & $\begin{array}{l}\text { GRC, CALC, } \\
\text { KTC, MRC } \\
\text { (Automated } \\
\text { controlled } \\
\text { force probe - } \\
0.50 \mathrm{~N} \text { ) }\end{array}$ & $\begin{array}{l}\text { University/hospi } \\
\text { tal-based } \\
\text { (Brazil) }\end{array}$ \\
\hline
\end{tabular}

This article is protected by copyright. All rights reserved. 


\begin{tabular}{|c|c|c|c|c|c|}
\hline & $\begin{array}{l}12 \\
\text { months' } \\
\text { duration }\end{array}$ & $\begin{array}{l}\text { I or II buccal } \\
\text { gingival } \\
\text { recessions } \\
\text { of at least } 3 \\
\mathrm{~mm}\end{array}$ & & & \\
\hline $\begin{array}{l}\text { Bouchard } \\
\text { et al. }\end{array}$ & $\begin{array}{l}\text { RCT, } \\
\text { parallel } \\
\text { design, } \\
2 \\
\text { treatme } \\
\text { nt } \\
\text { groups, } \\
6 \\
\text { months' } \\
\text { duration }\end{array}$ & $\begin{array}{l}30 \\
\text { individuals, } \\
24 \text { females, } \\
\text { aged } 21 \text { to } \\
62 \text { years, } \\
\text { with } 1 \text { Miller } \\
\text { Class I or II } \\
\text { buccal } \\
\text { gingival } \\
\text { recession of } \\
\text { at least } 3 \\
\text { mm }\end{array}$ & $\begin{array}{l}\text { 1. SCTG + CAF + CA (graft without } \\
\text { epithelial collar) } \\
\text { 2. SCTG (graft with epithelial collar) }\end{array}$ & $\begin{array}{l}\text { ACC, } \\
\text { GRC,CALC, } \\
\text { KTC, SCRC, } \\
\text { PCRC, MRC } \\
\text { (Automated } \\
\text { controlled } \\
\text { force probe - } \\
0.50 \mathrm{~N} \text { ) }\end{array}$ & $\begin{array}{l}\text { Practice-based } \\
\text { (France) }\end{array}$ \\
\hline $\begin{array}{l}\text { Bouchard } \\
\text { et al. }{ }^{30}\end{array}$ & $\begin{array}{l}\text { RCT, } \\
\text { parallel } \\
\text { design, } \\
2 \\
\text { treatme } \\
\text { nt } \\
\text { groups, } \\
6 \\
\text { months' } \\
\text { duration }\end{array}$ & $\begin{array}{l}30 \\
\text { individuals, } \\
25 \text { females, } \\
\text { aged } 21 \text { to } \\
70 \text { years, } \\
\text { with } 1 \text { Miller } \\
\text { Class I or II } \\
\text { buccal } \\
\text { gingival } \\
\text { recession of } \\
\text { at least } 3 \\
\text { mm }\end{array}$ & $\begin{array}{l}\text { 1. SCTG + CAF + TTC-HCl } \\
\text { 2. SCTG + CAF + CA }\end{array}$ & $\begin{array}{l}\text { GRC, CALC, } \\
\text { KTC, SCRC, } \\
\text { PCRC, MRC } \\
\text { (Automated } \\
\text { controlled } \\
\text { force probe - } \\
0.50 \mathrm{~N} \text { ) }\end{array}$ & $\begin{array}{l}\text { Practice-based } \\
\text { (France) }\end{array}$ \\
\hline $\begin{array}{l}\text { Costa et } \\
\text { al. }^{31,32}\end{array}$ & $\begin{array}{l}\text { RCT, } \\
\text { split- } \\
\text { mouth } \\
\text { design, } \\
2 \\
\text { treatme } \\
\text { nt } \\
\text { groups, } \\
6 \\
\text { months' } \\
\text { duration }\end{array}$ & $\begin{array}{l}20 \\
\text { individuals } \\
\text { (heavy } \\
\text { smokers - > } \\
10 \\
\text { cigarettes/d } \\
\text { ay for over } \\
5 \text { years), } 12 \\
\text { females, } \\
\text { aged } 30 \text { to } \\
50 \text { years, } \\
\text { with } 2 \\
\text { bilateral } \\
\text { Miller Class } \\
\text { I or II buccal } \\
\text { gingival } \\
\text { recessions } \\
\text { of at least } 3 \\
\text { mm }\end{array}$ & $\begin{array}{l}\text { 1. ADMG + EMD + CAF (extended } \\
\text { flap) } \\
\text { 2. ADMG + CAF (extended flap) }\end{array}$ & $\begin{array}{l}\text { GRC*(1), } \\
\text { CALC, KTC, } \\
\text { SCRC, } \\
\text { PCRC, MRC } \\
\text { (Automated } \\
\text { controlled } \\
\text { force probe } \\
\text { and } \\
\text { compass) }\end{array}$ & $\begin{array}{l}\text { University/hospi } \\
\text { tal-based } \\
\text { (Brazil) }\end{array}$ \\
\hline $\begin{array}{l}\text { Da Silva et } \\
\text { al. }^{33}\end{array}$ & $\begin{array}{l}\text { RCT, } \\
\text { split- } \\
\text { mouth } \\
\text { design, } \\
2 \\
\text { treatme } \\
\text { nt } \\
\text { groups, } \\
6 \\
\text { months' } \\
\text { duration }\end{array}$ & $\begin{array}{l}11 \\
\text { individuals, } \\
5 \text { females, } \\
\text { aged } 18 \text { to } \\
43 \text { years, } \\
\text { with } 2 \\
\text { bilateral } \\
\text { Miller Class } \\
\text { I or II buccal } \\
\text { gingival } \\
\text { recessions } \\
\text { of at least } 3 \\
\text { mm }\end{array}$ & $\begin{array}{l}\text { 1. } S C T G+C A F \\
\text { 2. } C A F\end{array}$ & $\begin{array}{l}\text { GRC, CALC, } \\
\text { KTC*}^{*}(1), \\
\text { SCRC, } \\
\text { PCRC, MRC } \\
\text { (Automated } \\
\text { controlled } \\
\text { force probe) }\end{array}$ & $\begin{array}{l}\text { University/hospi } \\
\text { tal-based } \\
\text { (Brazil) } \\
\text { Unpublished } \\
\text { data were } \\
\text { included } \\
\text { following } \\
\text { contact with } \\
\text { author }\end{array}$ \\
\hline
\end{tabular}




\begin{tabular}{|c|c|c|c|c|c|}
\hline $\begin{array}{l}\text { De Queiroz } \\
\text { et al. }{ }^{34,35}\end{array}$ & $\begin{array}{l}\text { RCT, } \\
\text { split- } \\
\text { mouth } \\
\text { design, } \\
2 \\
\text { treatme } \\
\text { nt } \\
\text { groups, } \\
24 \\
\text { months' } \\
\text { duration }\end{array}$ & $\begin{array}{l}13 \\
\text { individuals, } \\
7 \text { females, } \\
\text { mean age } \\
32.8 \text { years, } \\
\text { with } 2 \\
\text { bilateral } \\
\text { Miller Class } \\
\text { I buccal } \\
\text { gingival } \\
\text { recessions } \\
\text { of at least } 3 \\
\text { mm }\end{array}$ & $\begin{array}{l}\text { 1. } A D M G+C A F \\
\text { 2. } C A F\end{array}$ & $\begin{array}{l}\text { GRC, CALC, } \\
\text { KTC, SCRC, } \\
\text { PCRC, MRC } \\
\text { (Manual } \\
\text { probe) }\end{array}$ & $\begin{array}{l}\text { University/hospi } \\
\text { tal-based } \\
\text { (Brazil) }\end{array}$ \\
\hline $\begin{array}{l}\text { Del Pizzo et } \\
\text { al. }^{11}\end{array}$ & $\begin{array}{l}\text { RCT, } \\
\text { split- } \\
\text { mouth } \\
\text { design, } \\
2 \\
\text { treatme } \\
\text { nt } \\
\text { groups, } \\
24 \\
\text { months' } \\
\text { duration }\end{array}$ & $\begin{array}{l}15 \\
\text { individuals, } \\
11 \text { females, } \\
\text { aged } 18 \text { to } \\
56 \text { years, } \\
\text { with } 2 \\
\text { bilateral } \\
\text { Miller Class } \\
\text { I or II buccal } \\
\text { gingival } \\
\text { recessions } \\
\text { of at least } 3 \\
\text { mm }\end{array}$ & $\begin{array}{l}\text { 1. } E M D+C A F \\
\text { 2. } C A F\end{array}$ & $\begin{array}{l}\text { GRC, CALC, } \\
\text { KTC }^{*}(1), \\
\text { SCRC, } \\
\text { PCRC, MRC } \\
\text { (Manual } \\
\text { probe) }\end{array}$ & $\begin{array}{l}\text { University/hospi } \\
\text { tal-based (Italy) }\end{array}$ \\
\hline $\begin{array}{l}\text { Dodge et } \\
\text { al. }{ }^{36}\end{array}$ & $\begin{array}{l}\text { RCT, } \\
\text { split- } \\
\text { mouth } \\
\text { design, } \\
2 \\
\text { treatme } \\
\text { nt } \\
\text { groups, } \\
12 \\
\text { months' } \\
\text { duration }\end{array}$ & $\begin{array}{l}12 \\
\text { individuals, } \\
8 \text { females, } \\
\text { aged } 23 \text { to } \\
51 \text { years, } \\
\text { with } 2 \text { Miller } \\
\text { Class I or II } \\
\text { buccal } \\
\text { gingival } \\
\text { recessions } \\
\text { of at least } 3 \\
\text { mm }\end{array}$ & $\begin{array}{l}\text { 1. GTR (polylactic acid membrane - } \\
\text { Guidor) + TTC-HCl + DFDBA } \\
\text { 2. GTR (polylactic acid membrane - } \\
\text { Guidor) + TTC-HCl }\end{array}$ & $\begin{array}{l}\text { GRC, } \\
\text { CALC }^{*}(1), \\
\text { KTC }^{*}(1), \\
\text { SCRC } \\
\text { PCRC, MRC } \\
\text { (Manual } \\
\text { probe) }\end{array}$ & $\begin{array}{l}\text { Practice-based } \\
\text { (USA) }\end{array}$ \\
\hline $\begin{array}{l}\text { Henderson } \\
\text { et al. }{ }^{37}\end{array}$ & $\begin{array}{l}\text { RCT, } \\
\text { split- } \\
\text { mouth } \\
\text { design, } \\
2 \\
\text { treatme } \\
\text { nt } \\
\text { groups, } \\
12 \\
\text { months' } \\
\text { duration }\end{array}$ & $\begin{array}{l}10 \\
\text { individuals, } \\
5 \text { females, } \\
\text { aged } 24 \text { to } \\
68 \text { years, } \\
\text { with } 2 \text { Miller } \\
\text { Class I or II } \\
\text { buccal } \\
\text { gingival } \\
\text { recessions } \\
\text { of at least } 3 \\
\mathrm{~mm}\end{array}$ & $\begin{array}{l}\text { 1. ADMG (connective tissue side } \\
\text { against the tooth) + CAF } \\
\text { 2. ADMG (basement membrane } \\
\text { side against the tooth) + CAF }\end{array}$ & $\begin{array}{l}\text { GRC, CALC, } \\
\text { KTC, MRC } \\
\text { (Manual } \\
\text { probe) }\end{array}$ & $\begin{array}{l}\text { University/hospi } \\
\text { tal-based (USA) } \\
\text { and supported } \\
\text { by Lifecore } \\
\text { Biomedical }\end{array}$ \\
\hline $\begin{array}{l}\text { Jaiswal et } \\
\text { al. }^{38}\end{array}$ & $\begin{array}{l}\text { RCT, } \\
\text { parallel } \\
\text { design, } \\
2 \\
\text { treatme } \\
\text { nt } \\
\text { groups, } \\
6 \\
\text { months' } \\
\text { duration }\end{array}$ & $\begin{array}{l}20 \\
\text { individuals, } \\
8 \text { females, } \\
\text { aged } 25 \text { to } \\
56 \text { years, } \\
\text { with Miller } \\
\text { Class II } \\
\text { multiple } \\
\text { buccal } \\
\text { gingival } \\
\text { recessions } \\
\text { of at least } 3 \\
\text { mm }\end{array}$ & $\begin{array}{l}\text { 1. } E M D+C A F \\
\text { 2. } C A F\end{array}$ & $\begin{array}{l}\text { GRC*(1), } \\
\text { CALC*}^{*}(1), \\
\text { KTC, MRC } \\
\text { (Automated } \\
\text { controlled } \\
\text { force probe - } \\
\text { 15g) }\end{array}$ & $\begin{array}{l}\text { University/hospi } \\
\text { tal-based (India) }\end{array}$ \\
\hline
\end{tabular}




\begin{tabular}{|c|c|c|c|c|c|}
\hline $\begin{array}{l}\text { Jankovic et } \\
\text { al. }^{39}\end{array}$ & $\begin{array}{l}\text { RCT, } \\
\text { split- } \\
\text { mouth } \\
\text { design, } \\
2 \\
\text { treatme } \\
\text { nt } \\
\text { groups, } \\
12 \\
\text { months' } \\
\text { duration }\end{array}$ & $\begin{array}{l}20 \\
\text { individuals, } \\
12 \text { females, } \\
\text { aged } 21 \text { to } \\
48 \text { years, } \\
\text { with } \\
\text { bilateral } \\
\text { Miller Class } \\
\text { I and II } \\
\text { maxillary } \\
\text { buccal } \\
\text { gingival } \\
\text { recessions } \\
\text { of at least } 3 \\
\text { mm }\end{array}$ & $\begin{array}{l}\text { 1. Platelet-rich fibrin }+\mathrm{CAF} \\
\text { 2. } E M D+C A F\end{array}$ & $\begin{array}{l}\text { GRC, } \\
\text { KTC }^{*}(2), \\
\text { SCRC, } \\
\text { PCRC, MRC } \\
\text { (Manual } \\
\text { probe) }\end{array}$ & $\begin{array}{l}\text { University/hospi } \\
\text { tal-based } \\
\text { (Serbia) }\end{array}$ \\
\hline $\begin{array}{l}\text { Jepsen et } \\
\text { al. }^{40}\end{array}$ & $\begin{array}{l}\text { RCT, } \\
\text { split- } \\
\text { mouth } \\
\text { design, } \\
2 \\
\text { treatme } \\
\text { nt } \\
\text { groups, } \\
6 \\
\text { months' } \\
\text { duration }\end{array}$ & $\begin{array}{l}35 \\
\text { individuals, } \\
\text { age }>18 \\
\text { years, with } \\
2 \text { Miller } \\
\text { Class I or II } \\
\text { buccal } \\
\text { gingival } \\
\text { recessions } \\
\text { of at least } 3 \\
\mathrm{~mm}\end{array}$ & $\begin{array}{l}\text { 1. } X C M+C A F \\
\text { 2. } C A F\end{array}$ & $\begin{array}{l}\text { GRC*(1), } \\
\text { CALC, } \\
\operatorname{KTC}^{*}(1), \\
\text { SCRC, } \\
\text { PCRC, MRC } \\
\text { (Manual } \\
\text { probe) }\end{array}$ & $\begin{array}{l}\text { University/hospi } \\
\text { tal-based } \\
\text { (German, Italy, } \\
\text { Sweden and } \\
\text { Spain) and } \\
\text { supported by } \\
\text { Geistlich } \\
\text { Pharma AG }\end{array}$ \\
\hline Joly et al. ${ }^{41}$ & $\begin{array}{l}\text { RCT, } \\
\text { split- } \\
\text { mouth } \\
\text { design, } \\
2 \\
\text { treatme } \\
\text { nt } \\
\text { groups, } \\
6 \\
\text { months' } \\
\text { duration }\end{array}$ & $\begin{array}{l}10 \\
\text { individuals, } \\
4 \text { females, } \\
\text { aged } 24 \text { to } \\
68 \text { years, } \\
\text { with } 2 \text { Miller } \\
\text { Class I or II } \\
\text { maxillary } \\
\text { buccal } \\
\text { gingival } \\
\text { recessions } \\
\text { of at least } 3 \\
\text { mm }\end{array}$ & $\begin{array}{l}\text { 1. ADMG + CAF (flap without } \\
\text { vertical incisions) } \\
\text { 2. SCTG + CAF (flap without vertical } \\
\text { incisions) }\end{array}$ & $\begin{array}{l}\mathrm{GRC}^{*}(2), \\
\mathrm{CALC}^{*}(2), \\
\text { KTC, MRC } \\
\text { (Manual } \\
\text { probe) }\end{array}$ & $\begin{array}{l}\text { University/hospi } \\
\text { tal-based } \\
\text { (Brazil) }\end{array}$ \\
\hline $\begin{array}{l}\text { Keceli et } \\
\text { al. }^{42}\end{array}$ & $\begin{array}{l}\text { RCT, } \\
\text { parallel } \\
\text { design, } \\
2 \\
\text { treatme } \\
\text { nt } \\
\text { groups, } \\
12 \\
\text { months' } \\
\text { duration }\end{array}$ & $\begin{array}{l}40 \\
\text { individuals, } \\
30 \text { females, } \\
\text { aged } 18 \text { to } \\
60 \text { years, } \\
\text { with } 1 \text { Miller } \\
\text { Class I or II } \\
\text { buccal } \\
\text { gingival } \\
\text { recession of } \\
\text { at least } 3 \\
\text { mm. } 36 \\
\text { individuals } \\
\text { completed } \\
\text { the study }\end{array}$ & $\begin{array}{l}\text { 1. SCTG + platelet-rich plasma + } \\
\text { CAF } \\
\text { 2. SCTG + CAF }\end{array}$ & $\begin{array}{l}\text { GRC, CALC, } \\
\text { KTC, SCRC, } \\
\text { PCRC, MRC } \\
\text { (Manual } \\
\text { probe) }\end{array}$ & $\begin{array}{l}\text { University/hospi } \\
\text { tal-based } \\
\text { (Turkey) and } \\
\text { supported by } \\
\text { The Research } \\
\text { Foundation of } \\
\text { Hacettepe } \\
\text { University }\end{array}$ \\
\hline $\begin{array}{l}\text { Keceli et } \\
\text { al. }^{43}\end{array}$ & $\begin{array}{l}\text { RCT, } \\
\text { parallel } \\
\text { design, } \\
2 \\
\text { treatme } \\
\text { nt } \\
\text { groups, } \\
6 \\
\text { months' } \\
\text { duration }\end{array}$ & $\begin{array}{l}40 \\
\text { individuals, } \\
27 \text { females, } \\
\text { aged } 22 \text { to } \\
50 \text { years, } \\
\text { with } 1 \mathrm{Miller} \\
\text { Class I or II } \\
\text { buccal } \\
\text { gingival } \\
\text { recession of } \\
\text { at least } 3 \\
\text { mm }\end{array}$ & $\begin{array}{l}\text { 1. } S C T G+\text { platelet-rich fibrin + CAF } \\
\text { 2. SCTG + CAF }\end{array}$ & 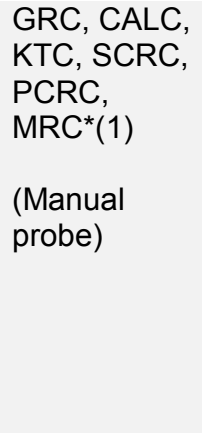 & $\begin{array}{l}\text { University/hospi } \\
\text { tal-based } \\
\text { (Turkey) }\end{array}$ \\
\hline
\end{tabular}

This article is protected by copyright. All rights reserved. 


\begin{tabular}{|c|c|c|c|c|c|}
\hline $\begin{array}{l}\text { Leknes et } \\
\text { al. } 44,45\end{array}$ & $\begin{array}{l}\text { RCT, } \\
\text { split- } \\
\text { mouth } \\
\text { design, } \\
2 \\
\text { treatme } \\
\text { nt } \\
\text { groups, } \\
72 \\
\text { months' } \\
\text { duration }\end{array}$ & $\begin{array}{l}20 \\
\text { individuals, } \\
10 \text { females, } \\
\text { mean age } \\
38.4 \text { years, } \\
\text { with } \\
2 \text { MillerClass } \\
\text { I or II buccal } \\
\text { gingival } \\
\text { recessions } \\
\text { of at least } 3 \\
\text { mm. } 11 \\
\text { individuals } \\
\text { completed } \\
\text { the study }\end{array}$ & $\begin{array}{l}\text { 1. GTR (polylactic acid membrane - } \\
\text { Guidor) } \\
\text { 2. CAF }\end{array}$ & $\begin{array}{l}\text { GRC, CALC, } \\
\text { KTC, SCRC, } \\
\text { PCRC, MRC } \\
\text { (Automated } \\
\text { controlled } \\
\text { force probe } \\
\text { and manual } \\
\text { probe) }\end{array}$ & $\begin{array}{l}\text { University/hospi } \\
\text { tal-based } \\
\text { (Norway) and } \\
\text { membranes } \\
\text { provided by } \\
\text { Guidor AB } \\
\text { Unpublished } \\
\text { data were } \\
\text { included } \\
\text { following } \\
\text { contact with } \\
\text { author }\end{array}$ \\
\hline $\begin{array}{l}\text { Matarasso } \\
\text { et al. }\end{array}$ & $\begin{array}{l}\mathrm{RCT}, \\
\text { parallel } \\
\text { design, } \\
2 \\
\text { treatme } \\
\mathrm{nt} \\
\text { groups, } \\
12 \\
\text { months' } \\
\text { duration }\end{array}$ & $\begin{array}{l}20 \\
\text { individuals, } \\
8 \text { females, } \\
\text { aged } 18 \text { to } \\
42 \text { years, } \\
\text { with } 1 \text { Miller } \\
\text { Class I or II } \\
\text { buccal } \\
\text { gingival } \\
\text { recession of } \\
\text { at least } 3 \\
\text { mm }\end{array}$ & $\begin{array}{l}\text { 1. GTR (polylactic acid membrane - } \\
\text { Guidor) + double papilla flap } \\
\text { 2. GTR (polylactic acid membrane - } \\
\text { Guidor) + CAF }\end{array}$ & $\begin{array}{l}\text { GRC, CALC, } \\
\text { KTC, MRC } \\
\text { (Manual } \\
\text { probe) }\end{array}$ & $\begin{array}{l}\text { University/hospi } \\
\text { tal-based (Italy) } \\
\text { Unpublished } \\
\text { data were } \\
\text { included } \\
\text { following } \\
\text { contact with } \\
\text { author }\end{array}$ \\
\hline $\begin{array}{l}\text { McGuire et } \\
\text { al. }^{47,48}\end{array}$ & $\begin{array}{l}\text { RCT, } \\
\text { split- } \\
\text { mouth } \\
\text { design, } \\
2 \\
\text { treatme } \\
\text { nt } \\
\text { groups, } \\
5 \text { years' } \\
\text { duration }\end{array}$ & $\begin{array}{l}20 \\
\text { individuals, } \\
10 \text { females, } \\
\text { aged } 23 \text { to } \\
62 \text { years, } \\
\text { with } 2 \text { Miller } \\
\text { Class II } \\
\text { maxillary } \\
\text { buccal } \\
\text { gingival } \\
\text { recessions } \\
\text { of at least } 4 \\
\text { mm. } 19 \\
\text { individuals } \\
\text { completed } \\
\text { the } 6 \text {-month } \\
\text { follow-up, } \\
17 \\
\text { completed } \\
\text { the } 12- \\
\text { month } \\
\text { follow-up, } \\
\text { and } 9 \text { the } 5 \text { - } \\
\text { year follow- } \\
\text { up }\end{array}$ & $\begin{array}{l}\text { 1. } E M D+C A F \\
\text { 2. SCTG + CAF }\end{array}$ & $\begin{array}{l}\text { GRC, CALC, } \\
\text { KTC }^{*}(2), \\
\text { PCRC, MRC } \\
\text { (Manual } \\
\text { probe) }\end{array}$ & $\begin{array}{l}\text { Practice-based } \\
\text { (USA) and } \\
\text { supported by } \\
\text { BIORA AB } \\
\text { (currently } \\
\text { Straumann) } \\
\text { Unpublished } \\
\text { data were } \\
\text { included } \\
\text { following } \\
\text { contact with } \\
\text { author }\end{array}$ \\
\hline $\begin{array}{l}\text { McGuire et } \\
\text { al. } 49,50\end{array}$ & $\begin{array}{l}\text { RCT, } \\
\text { split- } \\
\text { mouth } \\
\text { design, } \\
2 \\
\text { treatme } \\
\text { nt } \\
\text { groups, } \\
5 \text { years' } \\
\text { duration }\end{array}$ & $\begin{array}{l}30 \\
\text { individuals, } \\
26 \text { females, } \\
\text { aged } 18 \text { to } \\
70 \text { years, } \\
\text { with } 2 \text { Miller } \\
\text { Class II } \\
\text { buccal } \\
\text { gingival } \\
\text { recessions } \\
\text { of at least } 3 \\
\text { mm. } 30 \\
\text { individuals } \\
\text { completed } \\
\text { the } 6\end{array}$ & $\begin{array}{l}\text { 1. Beta-tricalcium phosphate (b- } \\
\text { TCP) + recombinant human platelet- } \\
\text { derived growth factor-B with a } \\
\text { bioabsorbable collagen wound- } \\
\text { healing dressing + CAF } \\
\text { 2. SCTG + CAF }\end{array}$ & $\begin{array}{l}\text { ACC, } \\
\text { GRC }^{\star}(2), \\
\text { CALC, } \\
\text { KTC }^{*}(2), \\
\text { SCC, PCRC, } \\
\text { MRC } \\
\text { (Manual } \\
\text { probe) }\end{array}$ & $\begin{array}{l}\text { Practice-based } \\
\text { (USA) and } \\
\text { supported by } \\
\text { Osteohealth } \\
\text { Unpublished } \\
\text { data were } \\
\text { included } \\
\text { following } \\
\text { contact with } \\
\text { author }\end{array}$ \\
\hline
\end{tabular}

This article is protected by copyright. All rights reserved. 
months

follow-up,

whereas

20 the 5

years

follow-up

\begin{tabular}{|c|c|c|c|c|c|}
\hline $\begin{array}{l}\text { McGuire et } \\
\text { al. }{ }^{12,51}\end{array}$ & $\begin{array}{l}\text { RCT, } \\
\text { split- } \\
\text { mouth } \\
\text { design, } \\
2 \\
\text { treatme } \\
\text { nt } \\
\text { groups, } \\
5 \text { years' } \\
\text { duration }\end{array}$ & $\begin{array}{l}25 \\
\text { individuals, } \\
17 \text { females, } \\
\text { aged } 18 \text { to } \\
70 \text { years, } \\
\text { with } 2 \text { Miller } \\
\text { Class II } \\
\text { buccal } \\
\text { gingival } \\
\text { recessions } \\
\text { of at least } 3 \\
\text { mm. } 23 \\
\text { individuals } \\
\text { completed } \\
\text { the } 12 \\
\text { months } \\
\text { follow-up, } \\
\text { whereas } \\
17 \text { the } 5 \\
\text { years } \\
\text { follow-up }\end{array}$ & $\begin{array}{l}\text { 1. } \mathrm{XCM}+\mathrm{CAF} \\
\text { 2. } \mathrm{SCTG}+\mathrm{CAF}\end{array}$ & $\begin{array}{l}\text { ACC, } \\
\text { GRC }^{*}(2), \\
\text { CALC }^{*}(2), \\
\text { KTC, SCC, } \\
\text { PCRC, MRC } \\
\text { (Manual } \\
\text { probe) }\end{array}$ & $\begin{array}{l}\text { Practice-based } \\
\text { (USA) and } \\
\text { supported by } \\
\text { Giestlich } \\
\text { Pharma AG } \\
\text { Unpublished } \\
\text { data were } \\
\text { included } \\
\text { following } \\
\text { contact with } \\
\text { author } \\
\text { Data from } \\
\text { earlier article } \\
\text { were reported } \\
\text { as part of this } \\
\text { trial }\end{array}$ \\
\hline $\begin{array}{l}\text { Öncü et } \\
\text { al. }^{52}\end{array}$ & $\begin{array}{l}\text { RCT, } \\
\text { split- } \\
\text { mouth } \\
\text { design, } \\
2 \\
\text { treatme } \\
\text { nt } \\
\text { groups, } \\
6 \\
\text { months' } \\
\text { duration }\end{array}$ & $\begin{array}{l}20 \\
\text { individuals, } \\
11 \text { females, } \\
\text { age }>18 \\
\text { years, with } \\
\text { maxillary } \\
\text { bilateral } \\
\text { multiple } \\
\text { Miller Class } \\
\text { I or II buccal } \\
\text { gingival } \\
\text { recession of } \\
\text { at least } 3 \\
\text { mm }\end{array}$ & $\begin{array}{l}\text { 1. Platelet-rich fibrin + CAF without } \\
\text { vertical incisions } \\
\text { 2. SCTG + CAF without vertical } \\
\text { incisions }\end{array}$ & $\begin{array}{l}\text { GRC, CALC, } \\
\text { KTC }^{*}(2), \\
\text { SCRC, } \\
\text { PCRC, MRC } \\
\text { (Manual } \\
\text { probe) }\end{array}$ & $\begin{array}{l}\text { University/hospi } \\
\text { tal-based } \\
\text { (Turkey) }\end{array}$ \\
\hline $\begin{array}{l}\text { Ozenci et } \\
\text { al. }^{53}\end{array}$ & $\begin{array}{l}\mathrm{RCT}, \\
\text { parallel } \\
\text { design, } \\
2 \\
\text { treatme } \\
\mathrm{nt} \\
\text { groups, } \\
12 \\
\text { months' } \\
\text { duration }\end{array}$ & $\begin{array}{l}20 \\
\text { individuals, } \\
13 \text { females, } \\
\text { aged } 22 \text { to } \\
42 \text { years, } \\
\text { with Miller } \\
\text { Class I } \\
\text { multiple } \\
\text { buccal } \\
\text { gingival } \\
\text { recessions } \\
\text { of at least } 3 \\
\text { mm }\end{array}$ & $\begin{array}{l}\text { 1. ADMG + Tunnel (CAF) } \\
\text { 2. ADMG + CAF }\end{array}$ & $\begin{array}{l}\operatorname{ACC}^{*}(2), \\
\operatorname{GRC}^{\star}(2), \\
\operatorname{CALC}^{*}(2), \\
\mathrm{KTC}^{*}(2), \\
\text { SCC, PCRC, } \\
\text { MRC } \\
\text { (Manual } \\
\text { probe) }\end{array}$ & $\begin{array}{l}\text { University/hospi } \\
\text { tal-based } \\
\text { (Turkey) }\end{array}$ \\
\hline $\begin{array}{l}\text { Paolantoni } \\
\text { o et al. }{ }^{54}\end{array}$ & $\begin{array}{l}\text { RCT, } \\
\text { parallel } \\
\text { design, } \\
2 \\
\text { treatme } \\
\text { nt } \\
\text { groups, } \\
60 \\
\text { months' } \\
\text { duration }\end{array}$ & $\begin{array}{l}70 \\
\text { individuals, } \\
38 \text { females, } \\
\text { aged } 25 \text { to } \\
48 \text { years, } \\
\text { with } 1 \text { Miller } \\
\text { Class I or II } \\
\text { buccal } \\
\text { gingival } \\
\text { recession of }\end{array}$ & $\begin{array}{l}\text { 1. SCTG + double papilla flap } \\
\text { 2. FGG }\end{array}$ & $\begin{array}{l}\text { GRC*(1), } \\
\text { KTC, SCRC, } \\
\text { PCRC, MRC } \\
\text { (Manual } \\
\text { probe) }\end{array}$ & $\begin{array}{l}\text { Practice-based } \\
\text { (Italy) } \\
\text { Unpublished } \\
\text { data were } \\
\text { included } \\
\text { following } \\
\text { contact with } \\
\text { author }\end{array}$ \\
\hline
\end{tabular}


at least 3

$\mathrm{mm}$

$\begin{array}{llll}\text { Paolantoni } & \text { RCT, } & 45 & \text { 1. GTR (polylactic acid membrane - } \\ \mathbf{0}^{55} & \text { parallel } & \text { individuals, } & \text { Guidor) } \\ \text { design, } & 31 \text { females, } & \text { 2. GTR (polylactic acid membrane - } \\ 3 & \text { aged } 27 \text { to } & \text { Paroguide) + } \\ \text { treatme } & 51 \text { years, } & \text { hydroxyapatite/collagen/chondroitin } \\ \text { nt } & \text { with 1Miller } & \text { sulfate } \\ \text { groups, } & \text { Class I or II } & \text { graft } \\ 12 & \text { buccal } & \text { 3. SCTG + double papilla flap } \\ \text { months' } & \text { gingival } & \\ \text { duration } & \begin{array}{l}\text { recession of } \\ \text { at least 3 } \\ \end{array} & \\ & \text { mm }\end{array}$

GRC, CALC, University/hospi $\mathrm{KTC}^{*}(3), \quad$ tal-based (Italy) SCRC, and supported PCRC, MRC by

(Manual ItalianMinistry of

probe) Scientific

Research

Unpublished

data were

included

following

contact with

author

$\begin{array}{llll}\text { Paolantoni } & \text { RCT, } & \text { 30 } & \text { 1. ADMG + CAF } \\ \text { o et al. }^{56} & \text { parallel } & \text { individuals, } & \text { 2. SCTG + CAF } \\ \text { design, } & \text { 19 females, } \\ 2 & \text { aged } 29 \text { to } \\ \text { treatme } & 51 \text { years, } \\ \text { nt } & \text { with 1Miller } & \\ \text { groups, } & \text { Class I or II } \\ 12 & \text { buccal } & \\ \text { months' } & \text { gingival } \\ \text { duration } & \text { recession of } \\ & & \text { at least 3 } \\ & \text { mm }\end{array}$

GRC, CALC, University/hospi $\operatorname{KTC}^{*}(2)$,

SCRC,

PCRC, MRC

(Automated

controlled

tal-based (Italy)

and supported

by

ItalianMinistry of

force probe - Research

$20 \mathrm{~g}$ and

calliper)

Unpublished

data were

included

following

contact with

author

\begin{tabular}{|c|c|c|c|c|c|}
\hline $\begin{array}{l}\text { Pendor et } \\
\text { al. }{ }^{57}\end{array}$ & $\begin{array}{l}\mathrm{RCT}, \\
\text { parallel } \\
\text { design, } \\
2 \\
\text { treatme } \\
\text { nt } \\
\text { groups, } \\
6 \\
\text { months' } \\
\text { duration }\end{array}$ & $\begin{array}{l}20 \\
\text { individuals, } \\
6 \text { females, } \\
\text { aged } 25 \text { to } \\
46 \text { years, } \\
\text { with } 1 \text { Miller } \\
\text { Class I or II } \\
\text { buccal } \\
\text { gingival } \\
\text { recession of } \\
\text { at least } 3 \\
\text { mm }\end{array}$ & $\begin{array}{l}\text { 1. SCTG + double pedicle flap } \\
\text { 2. SCTG + CAF }\end{array}$ & $\begin{array}{l}\text { GRC, CALC, } \\
\text { KTC, SCRC, } \\
\text { PCRC, MRC } \\
\text { (Automated } \\
\text { controlled } \\
\text { force probe - } \\
15 \text { g and } \\
\text { calliper) }\end{array}$ & $\begin{array}{l}\text { University/hospi } \\
\text { tal-based (India) }\end{array}$ \\
\hline $\begin{array}{l}\text { Rasperini } \\
\text { et al. }\end{array}$ & $\begin{array}{l}\text { RCT, } \\
\text { parallel } \\
\text { design, } \\
2 \\
\text { treatme } \\
\text { nt } \\
\text { groups, } \\
12 \\
\text { months' } \\
\text { duration }\end{array}$ & $\begin{array}{l}56 \\
\text { individuals, } \\
39 \text { females, } \\
\text { mean } 35.5 \\
\text { years, with } \\
1 \text { Miller } \\
\text { Class I or II } \\
\text { buccal } \\
\text { gingival } \\
\text { recession of } \\
\text { at least } 3 \\
\text { mm }\end{array}$ & $\begin{array}{l}\text { 1. } E M D+S C T G+C A F \\
\text { 2. SCTG + CAF }\end{array}$ & $\begin{array}{l}\text { GRC, CALC, } \\
\text { KTC, SCRC, } \\
\text { PCRC, MRC } \\
\text { (Manual } \\
\text { probe) }\end{array}$ & $\begin{array}{l}\text { University/hospi } \\
\text { tal-based (Italy) }\end{array}$ \\
\hline $\begin{array}{l}\text { Reino et } \\
\text { al. }^{59}\end{array}$ & $\begin{array}{l}\text { RCT, } \\
\text { split- } \\
\text { mouth } \\
\text { design, } \\
2 \\
\text { treatme } \\
\text { nt } \\
\text { groups, } \\
6\end{array}$ & $\begin{array}{l}12 \\
\text { individuals } \\
\text { (heavy } \\
\text { smokers - } \geq \\
20 \\
\text { cigarettes } \\
\text { per day for } \\
\text { more than } 5 \\
\text { years), } 10\end{array}$ & $\begin{array}{l}\text { 1. SCTG + CAF (extended flap) } \\
\text { 2. SCTG + CAF }\end{array}$ & $\begin{array}{l}\text { SCRC, } \\
\text { PCRC, MRC } \\
\text { (Automated } \\
\text { controlled } \\
\text { force probe } \\
\text { and manual } \\
\text { probe) }\end{array}$ & $\begin{array}{l}\text { University/hospi } \\
\text { tal-based } \\
\text { (Brazil) and } \\
\text { supported by } \\
\text { the State of São } \\
\text { Paulo Research } \\
\text { Foundation, } \\
\text { São Paulo, } \\
\text { Brazil }\end{array}$ \\
\hline
\end{tabular}

This article is protected by copyright. All rights reserved. 


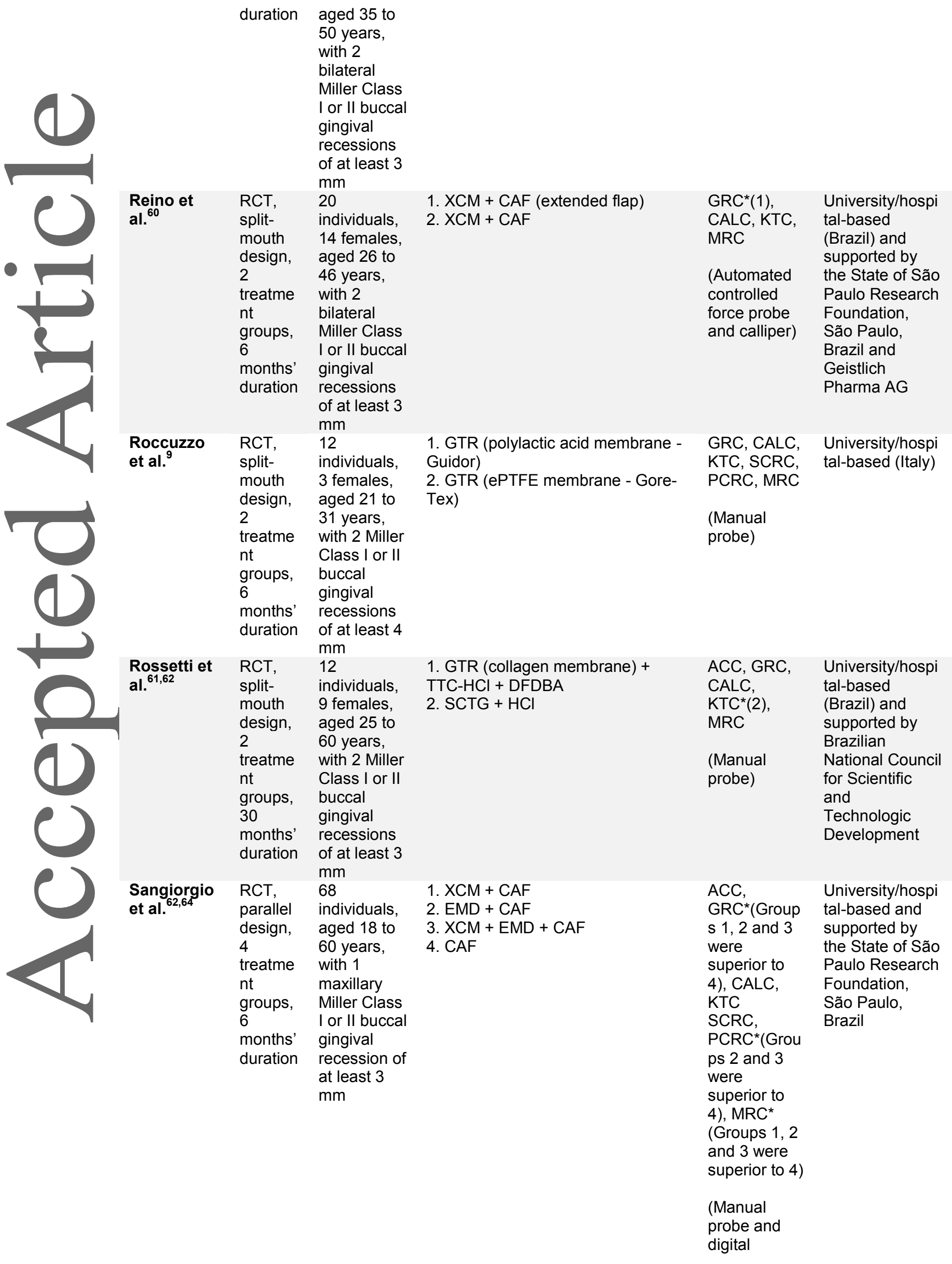

This article is protected by copyright. All rights reserved. 
calliper)

\begin{tabular}{|c|c|c|c|c|c|}
\hline $\begin{array}{l}\text { Shori et } \\
\text { al. } 55\end{array}$ & $\begin{array}{l}\text { RCT, } \\
\text { parallel } \\
\text { design, } \\
2 \\
\text { treatme } \\
\mathrm{nt} \\
\text { groups, } \\
6 \\
\text { months' } \\
\text { duration }\end{array}$ & $\begin{array}{l}20 \\
\text { individuals, } \\
\text { aged } 18 \text { to } \\
50 \text { years, } \\
\text { with } 1 \text { Miller } \\
\text { Class I or II } \\
\text { buccal } \\
\text { gingival } \\
\text { recessions } \\
\text { of at least } 3 \\
\mathrm{~mm}\end{array}$ & $\begin{array}{l}\text { 1. } A D M G+C A F \\
\text { 2. SCTG + CAF }\end{array}$ & $\begin{array}{l}\text { GRC, CALC, } \\
\mathrm{KTC}^{*}(2), \\
\text { SCR, PCRC, } \\
\text { MRC } \\
\text { (Automated } \\
\text { controlled } \\
\text { force probe) }\end{array}$ & $\begin{array}{l}\text { University/hospi } \\
\text { tal-based (India) }\end{array}$ \\
\hline $\begin{array}{l}\text { Spahr et } \\
\text { al. }\end{array}$ & $\begin{array}{l}\text { RCT, } \\
\text { split- } \\
\text { mouth } \\
\text { design, } \\
2 \\
\text { treatme } \\
\text { nt } \\
\text { groups, } \\
24 \\
\text { months' } \\
\text { duration }\end{array}$ & $\begin{array}{l}37 \\
\text { individuals, } \\
17 \text { females, } \\
\text { aged } 22 \text { to } \\
62 \text { years, } \\
\text { with } 2 \text { Miller } \\
\text { Class I or II } \\
\text { buccal } \\
\text { gingival } \\
\text { recessions } \\
\text { of at least } 3 \\
\text { mm. } 30 \\
\text { individuals } \\
\text { completed } \\
\text { the study }\end{array}$ & $\begin{array}{l}\text { 1. } E M D+C A F \\
\text { 2. Placebo (propylene glycol } \\
\text { alginate) + CA }\end{array}$ & $\begin{array}{l}\text { GRC, CALC, } \\
\text { KTC, PCRC, } \\
\text { MRC } \\
\text { (Automated } \\
\text { controlled } \\
\text { force probe, } \\
\text { calliper and } \\
\text { manual } \\
\text { probe) }\end{array}$ & $\begin{array}{l}\text { University/hospi } \\
\text { tal-based } \\
\text { (Germany)and } \\
\text { supported by } \\
\text { BIORA AB } \\
\text { (currently } \\
\text { Straumann) }\end{array}$ \\
\hline $\begin{array}{l}\text { Tözum et } \\
\text { al. }{ }^{68}\end{array}$ & $\begin{array}{l}\mathrm{RCT}, \\
\text { parallel } \\
\text { design, } \\
2 \\
\text { treatme } \\
\mathrm{nt} \\
\text { groups, } \\
6 \\
\text { months' } \\
\text { duration }\end{array}$ & $\begin{array}{l}31 \\
\text { individuals, } \\
21 \text { females, } \\
\text { aged } 16 \text { to } \\
59 \text { years, } \\
\text { with } 1 \text { Miller } \\
\text { Class I or II } \\
\text { buccal } \\
\text { gingival } \\
\text { recession of } \\
\text { at least } 3 \\
\text { mm }\end{array}$ & $\begin{array}{l}\text { 1. SCTG + modified tunnel } \\
\text { procedure } \\
\text { 2. SCTG + CAF }\end{array}$ & $\begin{array}{l}\text { GRC }^{*}(1), \\
\text { CALC }^{*}(1), \\
\text { MRC } \\
\text { (Manual } \\
\text { probe) }\end{array}$ & $\begin{array}{l}\text { University/hospi } \\
\text { tal-based } \\
\text { (Turkey) } \\
\text { Unpublished } \\
\text { data were } \\
\text { included } \\
\text { following } \\
\text { contact with } \\
\text { author }\end{array}$ \\
\hline $\begin{array}{l}\text { Trombelli } \\
\text { et al. }{ }^{69}\end{array}$ & $\begin{array}{l}\text { RCT, } \\
\text { split- } \\
\text { mouth } \\
\text { design, } \\
2 \\
\text { treatme } \\
\text { nt } \\
\text { groups, } \\
6 \\
\text { months' } \\
\text { duration }\end{array}$ & $\begin{array}{l}15 \\
\text { individuals, } \\
3 \text { females, } \\
\text { aged } 25 \text { to } \\
51 \text { years, } \\
\text { with } 2 \text { Miller } \\
\text { Class I or II } \\
\text { maxillary } \\
\text { buccal } \\
\text { gingival } \\
\text { recessions } \\
\text { of at least } 3 \\
\mathrm{~mm}\end{array}$ & $\begin{array}{l}\text { 1. } \mathrm{CAF} \text { (fibrin glue }+\mathrm{TTC}-\mathrm{HCl}) \\
\text { 2. } \mathrm{CAF}(\mathrm{TTC}-\mathrm{HCl})\end{array}$ & $\begin{array}{l}\text { GRC, CALC, } \\
\text { KTC, SCRC, } \\
\text { PCRC, MRC } \\
\text { (Manual } \\
\text { probe) }\end{array}$ & $\begin{array}{l}\text { University/hospi } \\
\text { tal-based (Italy) } \\
\text { and supported } \\
\text { by Italian } \\
\text { Ministry of } \\
\text { University and } \\
\text { Scientific } \\
\text { Research }\end{array}$ \\
\hline
\end{tabular}

This article is protected by copyright. All rights reserved. 


\begin{tabular}{|c|c|c|c|c|c|}
\hline $\begin{array}{l}\text { Tunali et } \\
\text { al. }^{70}\end{array}$ & $\begin{array}{l}\text { RCT, } \\
\text { split- } \\
\text { mouth } \\
\text { design, } \\
2 \\
\text { treatme } \\
\text { nt } \\
\text { groups, } \\
12 \\
\text { months' } \\
\text { duration }\end{array}$ & $\begin{array}{l}10 \\
\text { individuals, } \\
6 \text { female, } \\
\text { aged } 25 \text { to } \\
52 \text { years, } \\
\text { with } 2 \text { Miller } \\
\text { Class I or II } \\
\text { multiple } \\
\text { buccal } \\
\text { gingival } \\
\text { recessions } \\
\text { of at least } 3 \\
\text { mm }\end{array}$ & $\begin{array}{l}\text { 1. Leukocyte- and platelet-rich fibrin } \\
+ \text { CAF } \\
\text { 2. SCTG + CAF }\end{array}$ & $\begin{array}{l}\text { GRC, CALC, } \\
\text { KTC, SCRC, } \\
\text { PCRC, MRC } \\
\text { (Manual } \\
\text { probe) }\end{array}$ & $\begin{array}{l}\text { University/hospi } \\
\text { tal-based (Italy) } \\
\text { Unpublished } \\
\text { data were } \\
\text { included } \\
\text { following } \\
\text { contact with } \\
\text { author }\end{array}$ \\
\hline $\begin{array}{l}\text { Wang et } \\
\text { al. }^{71}\end{array}$ & $\begin{array}{l}\text { RCT, } \\
\text { split- } \\
\text { mouth } \\
\text { design, } \\
2 \\
\text { treatme } \\
\text { nt } \\
\text { groups, } \\
6 \\
\text { months' } \\
\text { duration }\end{array}$ & $\begin{array}{l}16 \\
\text { individuals, } \\
10 \text { females, } \\
\text { aged } 30 \text { to } \\
54 \text { years, } \\
\text { with } 2 \text { Miller } \\
\text { Class I or II } \\
\text { buccal } \\
\text { gingival } \\
\text { recessions } \\
\text { of at least } 3 \\
\text { mm }\end{array}$ & $\begin{array}{l}\text { 1. GTR (reabsorbable double } \\
\text { thickness collagen membrane - } \\
\text { Sulzer Dental Inc) } \\
\text { 2. SCTG + CAF }\end{array}$ & $\begin{array}{l}\text { ACC, GRC, } \\
\text { CALC, KTC, } \\
\text { MRC } \\
\text { (Manual } \\
\text { probe) }\end{array}$ & $\begin{array}{l}\text { University/hospi } \\
\text { tal-based (USA) } \\
\text { and supported } \\
\text { by Sulzer } \\
\text { Calcitek Inc }\end{array}$ \\
\hline $\begin{array}{l}\text { Woodyard } \\
\text { et al. }\end{array}$ & $\begin{array}{l}\mathrm{RCT}, \\
\text { parallel } \\
\text { design, } \\
2 \\
\text { treatme } \\
\mathrm{nt} \\
\text { groups, } \\
6 \\
\text { months' } \\
\text { duration }\end{array}$ & $\begin{array}{l}24 \\
\text { individuals, } \\
14 \\
\text { females,me } \\
\text { an age } 34.6 \\
\text { years, with } \\
1 \text { Miller } \\
\text { Class I or II } \\
\text { buccal } \\
\text { gingival } \\
\text { recession of } \\
\text { at least } 3 \\
\mathrm{~mm}\end{array}$ & $\begin{array}{l}\text { 1. } A D M G+C A F \\
\text { 2. } C A F\end{array}$ & $\begin{array}{l}\text { GRC*}^{*}(1), \\
\text { CALC*(1), } \\
\text { KTC, SCRC, } \\
\text { PCRC, MRC } \\
\text { (Manual } \\
\text { probe) }\end{array}$ & $\begin{array}{l}\text { University/hospi } \\
\text { tal-based (USA) }\end{array}$ \\
\hline $\begin{array}{l}\text { Zucchelli et } \\
\text { al. }^{10}\end{array}$ & $\begin{array}{l}\mathrm{RCT}, \\
\text { parallel } \\
\text { design, } \\
3 \\
\text { treatme } \\
\mathrm{nt} \\
\text { groups, } \\
12 \\
\text { months' } \\
\text { duration }\end{array}$ & $\begin{array}{l}54 \\
\text { individuals, } \\
29 \text { females, } \\
\text { aged } 23 \text { to } \\
33 \text { years, } \\
\text { with } 1 \text { Miller } \\
\text { Class I or II } \\
\text { buccal } \\
\text { gingival } \\
\text { recession of } \\
\text { at least } 3 \\
\text { mm }\end{array}$ & $\begin{array}{l}\text { 1. GTR (polylactic acid membrane - } \\
\text { Guidor) } \\
\text { 2. GTR (ePTFE membrane - Gore- } \\
\text { Tex) } \\
\text { 3. SCTG + CAF }\end{array}$ & $\begin{array}{l}\text { GRC, CALC, } \\
\text { KTC }^{\star}(3), \\
\text { SCRC, } \\
\text { PCRC, MRC } \\
\text { (Manual } \\
\text { probe) }\end{array}$ & $\begin{array}{l}\text { University/hospi } \\
\text { tal-based (Italy) }\end{array}$ \\
\hline $\begin{array}{l}\text { Zucchelli et } \\
\text { al. }^{72}\end{array}$ & $\begin{array}{l}\text { RCT, } \\
\text { split- } \\
\text { mouth } \\
\text { design, } \\
2 \\
\text { treatme } \\
\text { nt } \\
\text { groups, } \\
12 \\
\text { months' } \\
\text { duration }\end{array}$ & $\begin{array}{l}15 \\
\text { individuals, } \\
\text { aged } 18 \text { to } \\
35 \text { years, } \\
\text { with } 2 \text { Miller } \\
\text { Class I or II } \\
\text { maxillary } \\
\text { buccal } \\
\text { gingival } \\
\text { recessions } \\
\text { of at least } 3 \\
\mathrm{~mm}\end{array}$ & $\begin{array}{l}\text { 1. SCTG (graft size equal to the } \\
\text { bone dehiscence) + CAF } \\
\text { 2. SCTG (graft size } 3 \mathrm{~mm} \text { greater } \\
\text { than the bone dehiscence) + CAF }\end{array}$ & $\begin{array}{l}\text { ACC, GRC, } \\
\text { CALC }^{*}(1), \\
\text { KTC }^{*}(2), \\
\text { SCRC, } \\
\text { PCRC, MRC } \\
\text { (Manual } \\
\text { pressure } \\
\text { sensitive } \\
\text { probe) }\end{array}$ & $\begin{array}{l}\text { University/hospi } \\
\text { tal-based (Italy) }\end{array}$ \\
\hline $\begin{array}{l}\text { Zucchelli et } \\
\text { al. }^{73}\end{array}$ & $\begin{array}{l}\text { RCT, } \\
\text { split- } \\
\text { mouth } \\
\text { design, } \\
2\end{array}$ & $\begin{array}{l}11 \\
\text { individuals, } \\
\text { aged } 18 \text { to } \\
40 \text { years, } \\
\text { with } 2 \text { Miller }\end{array}$ & $\begin{array}{l}\text { 1. Ultrasonic instrumentation - CAF } \\
\text { 2. Hand instrumentation - CAF }\end{array}$ & $\begin{array}{l}\text { GRC, CALC, } \\
\text { KTC, SCRC, } \\
\text { PCRC, MRC } \\
\text { (Manual }\end{array}$ & $\begin{array}{l}\text { University/hospi } \\
\text { tal-based (Italy) }\end{array}$ \\
\hline
\end{tabular}

This article is protected by copyright. All rights reserved. 


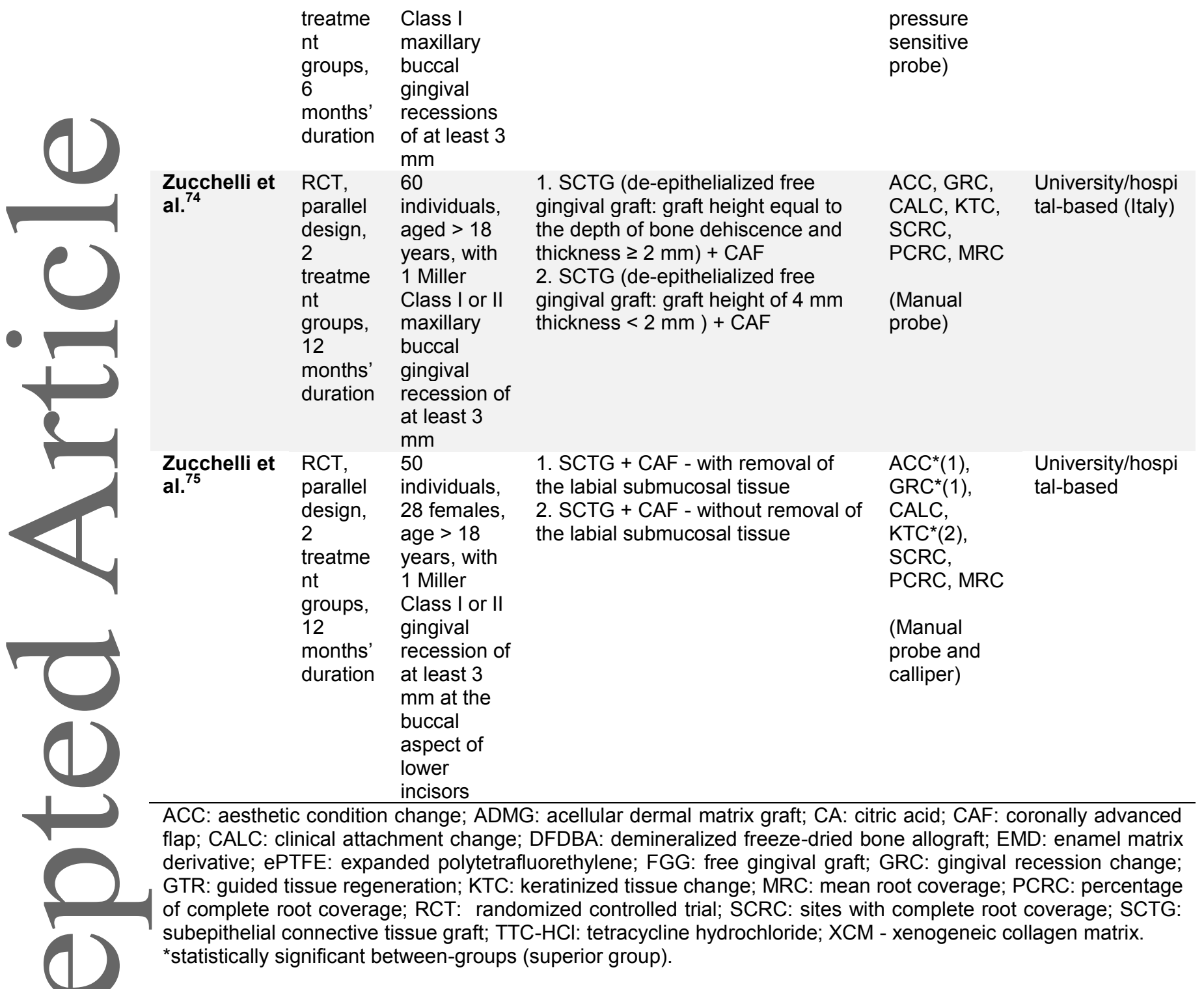

This article is protected by copyright. All rights reserved. 
Table 2 - Root coverage outcomes (i.e., complete root coverage and mean root coverage) and aesthetic condition change

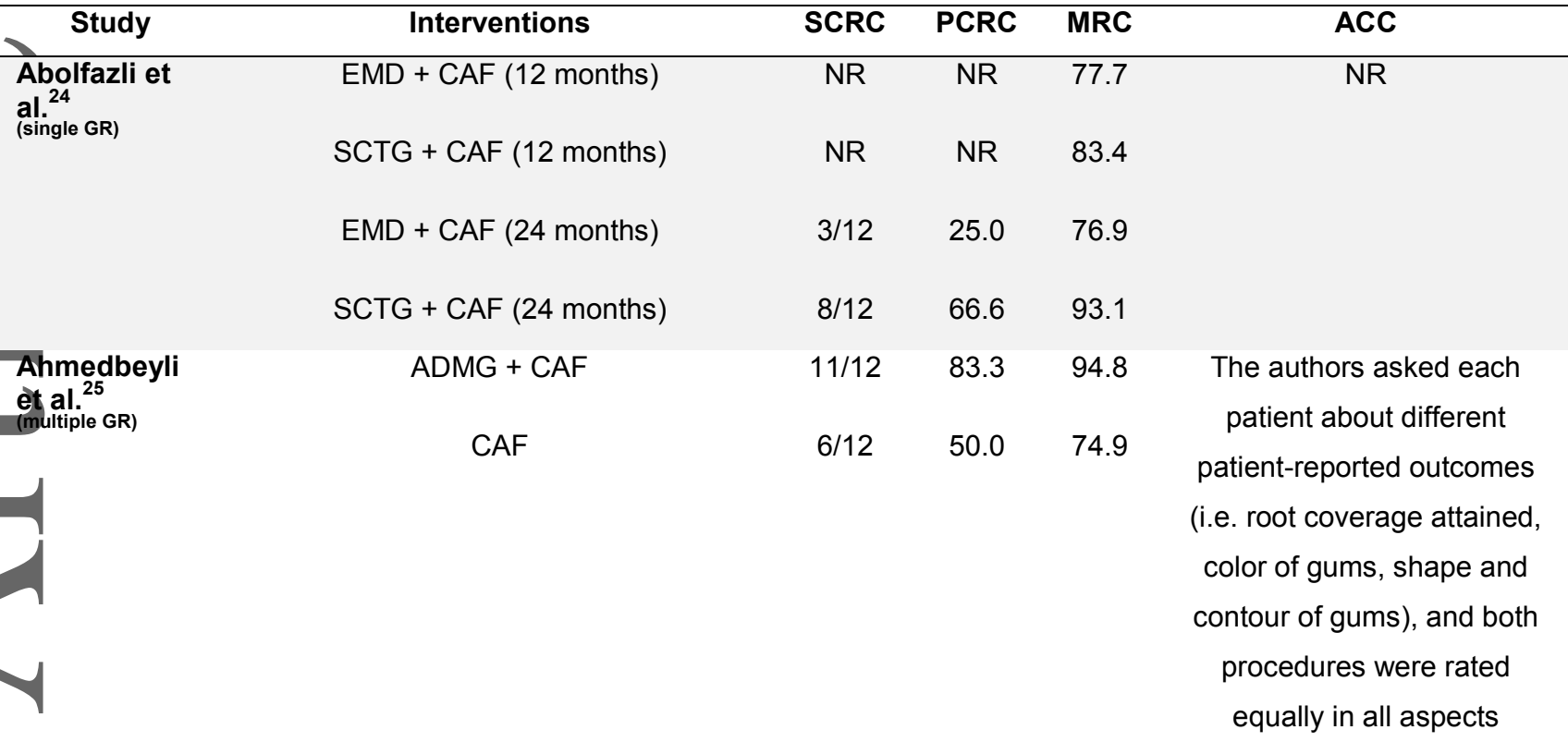

\begin{tabular}{|c|c|c|c|c|c|}
\hline \multirow[t]{2}{*}{$\underset{(\text { single GR) }}{\text { Ayub et al. }}$} & $\begin{array}{c}\text { ADMG (1 mm apical to the CEJ) + CAF } \\
\text { (extended flap) }\end{array}$ & $4 / 15$ & 26.6 & 88.4 & \multirow[t]{2}{*}{ NR } \\
\hline & ADMG + CAF (extended flap) & $0 / 15$ & 0 & 65.8 & \\
\hline abu et al. ${ }^{2 \prime}$ & GTR (collagen membrane) + CAF & NR & NR & 84.0 & \multirow[t]{2}{*}{ NR } \\
\hline & SCTG + CAF & NR & NR & 84.8 & \\
\hline rros et & ADMG + CAF (extended flap) & NR & NR & 80.7 & \multirow[t]{2}{*}{ NR } \\
\hline & SCTG + CAF (extended flap) & NR & NR & 78.7 & \\
\hline $\begin{array}{l}\text { Bouchard et } \\
\text { al } 29 \\
\text { (single GR) }\end{array}$ & $\begin{array}{l}\text { SCTG + CAF + citric acid (graft without } \\
\text { epithelial collar) } \\
\text { SCTG (graft with epithelial collar) }\end{array}$ & $3 / 15$ & 20.0 & $\begin{array}{l}69.7 \\
64.7\end{array}$ & $\begin{array}{l}\text { Aesthetic evaluation was } \\
\text { performed by } 2 \text { independent } \\
\text { examiners who were blinded } \\
\text { to the given treatment. } \\
\text { Additionally, the authors } \\
\text { commented that no patient } \\
\text { was dissatisfied with the } \\
\text { aesthetical results obtained }\end{array}$ \\
\hline \multirow[t]{2}{*}{$\begin{array}{l}\text { Bouchard et } \\
\text { al. }{ }^{30} \\
\text { (single GR) }\end{array}$} & $\begin{array}{l}\text { SCTG + CAF + tetracycline } \\
\text { hydrochloride }\end{array}$ & $6 / 15$ & 40.0 & 79.3 & \multirow[t]{2}{*}{ NR } \\
\hline & SCTG + CAF + citric acid & $8 / 15$ & 53.3 & 84.0 & \\
\hline \multirow[t]{3}{*}{$\begin{array}{l}\text { Costa et } \\
\text { al. }{ }^{31,32} \\
\text { (single GR) }\end{array}$} & $\begin{array}{c}\text { ADMG + EMD + CAF (6 months) } \\
\text { ADMG + CAF (6 months) }\end{array}$ & $\begin{array}{l}3 / 19 \\
1 / 19\end{array}$ & $\begin{array}{l}15.8 \\
5.3\end{array}$ & $\begin{array}{l}55.4 \\
44.0\end{array}$ & \multirow[t]{3}{*}{ NR } \\
\hline & $A D M G+E M D+C A F$ (12 months) & $3 / 19$ & & 59.7 & \\
\hline & ADMG + CAF (12 months) & $1 / 19$ & & 52.8 & \\
\hline
\end{tabular}

This article is protected by copyright. All rights reserved. 


\begin{tabular}{|c|c|c|c|c|c|}
\hline $\begin{array}{l}\text { da Silva et } \\
\text { al. }^{33} \\
\text { (single GR) }\end{array}$ & $\begin{array}{c}\mathrm{SCTG}+\mathrm{CAF} \\
\mathrm{CAF}\end{array}$ & $2 / 11$ & 18.1 & 75.3 & $N R$ \\
\hline \multirow{6}{*}{$\begin{array}{l}\text { de Queiroz et } \\
\text { al }{ }^{34,35} \\
\text { (single GR) }\end{array}$} & ADMG + CAF (6 months) & $3 / 13$ & 23.0 & 76.0 & \multirow[t]{6}{*}{ NR } \\
\hline & CAF (6 months) & $3 / 13$ & 23.0 & 71.0 & \\
\hline & ADMG + CAF (12 months) & $2 / 13$ & 15.3 & 71.0 & \\
\hline & CAF (12 months) & $2 / 13$ & 15.3 & 66.7 & \\
\hline & ADMG + CAF (24 months) & $1 / 13$ & 7.7 & 68.4 & \\
\hline & CAF (24 months) & $1 / 13$ & 7.7 & 55.9 & \\
\hline \multirow{2}{*}{$\begin{array}{l}\text { Del Pizzo et } \\
\text { a! }{ }^{11} \\
\text { (single GR) }\end{array}$} & $\mathrm{EMD}+\mathrm{CAF}$ & $11 / 15$ & 73.3 & 90.7 & \multirow[t]{2}{*}{$N R$} \\
\hline & CAF & $9 / 15$ & 60.0 & 86.7 & \\
\hline \multirow{2}{*}{$\begin{array}{l}\text { Dodge et al al } \\
\text { (single GR) }\end{array}$} & $\begin{array}{l}\text { GTR (polylactide membrane - Guidor) + } \\
\text { tetracycline hydrochloride + DFDBA + }\end{array}$ & $6 / 12$ & 50.0 & 89.9 & \multirow[t]{2}{*}{ NR } \\
\hline & CAF & $4 / 12$ & 33.3 & 73.7 & \\
\hline \multirow{3}{*}{$\begin{array}{l}\text { Henderson et } \\
\text { al }{ }^{37} \\
\text { (single GR) }\end{array}$} & $\begin{array}{l}\text { GTR (polylactide membrane - Guidor) + } \\
\text { tetracycline hydrochloride + CAF }\end{array}$ & & & & \\
\hline & $\begin{array}{l}\text { ADMG (basement membrane side } \\
\text { against the tooth) + CAF }\end{array}$ & $7 / 10$ & 70.0 & 94.9 & \multirow[t]{2}{*}{ NR } \\
\hline & $\begin{array}{c}\text { ADMG (connective tissue side against } \\
\text { the tooth) + CAF }\end{array}$ & $8 / 10$ & 80.0 & 95.5 & \\
\hline \multirow{2}{*}{$\begin{array}{l}\text { Jäiswal et } \\
\text { al. } \\
\text { (multiple GR) }\end{array}$} & $\mathrm{EMD}+\mathrm{CAF}$ & NR & NR & 86.3 & \multirow[t]{2}{*}{ NR } \\
\hline & $\mathrm{CAF}$ & NR & NR & 79.6 & \\
\hline \multirow{2}{*}{$\begin{array}{l}\text { Jankovic et } \\
\text { al }{ }^{39} \\
\text { (single GR) }\end{array}$} & Platelet-rich fibrin + CAF & $12 / 20$ & 60.0 & 72.1 & \multirow[t]{2}{*}{ NR } \\
\hline & $\mathrm{EMD}+\mathrm{CAF}$ & $13 / 20$ & 65.0 & 70.5 & \\
\hline \multirow{2}{*}{$\begin{array}{l}\text { Jepsen et } \\
\text { al }{ }^{40} \\
\text { (single GR) }\end{array}$} & $\mathrm{XCM}+\mathrm{CAF}$ & $29 / 35$ & 82.8 & 72.0 & \multirow[t]{2}{*}{ NR } \\
\hline & $\mathrm{CAF}$ & $17 / 35$ & 48.6 & 66.2 & \\
\hline \multirow[t]{2}{*}{$\begin{array}{l}\text { Joly et al. }{ }^{41} \\
\text { (single GR) }\end{array}$} & $A D M G+C A F$ (without vertical incisions) & NR & NR & 50.0 & \multirow[t]{2}{*}{ NR } \\
\hline & SCTG + CAF (without vertical incisions) & NR & NR & 79.5 & \\
\hline \multirow{2}{*}{$\underset{\text { (single GR) }}{\text { Keceli et al. }}{ }^{42}$} & SCTG + platelet-rich plasma + CAF & $6 / 17$ & 35.3 & 86.4 & \multirow[t]{2}{*}{ NR } \\
\hline & $\mathrm{SCTG}+\mathrm{CAF}$ & $8 / 19$ & 42.1 & 86.4 & \\
\hline \multirow[t]{2}{*}{$\underset{\text { (single GR) }}{\text { Keceli et al. }{ }^{43}}$} & $\mathrm{SCTG}+$ platelet-rich fibrin $+\mathrm{CAF}$ & $11 / 20$ & $55.0 \%$ & 89.6 & \multirow[t]{2}{*}{ NR } \\
\hline & $\mathrm{SCTG}+\mathrm{CAF}$ & $7 / 20$ & $35.0 \%$ & 79.9 & \\
\hline
\end{tabular}




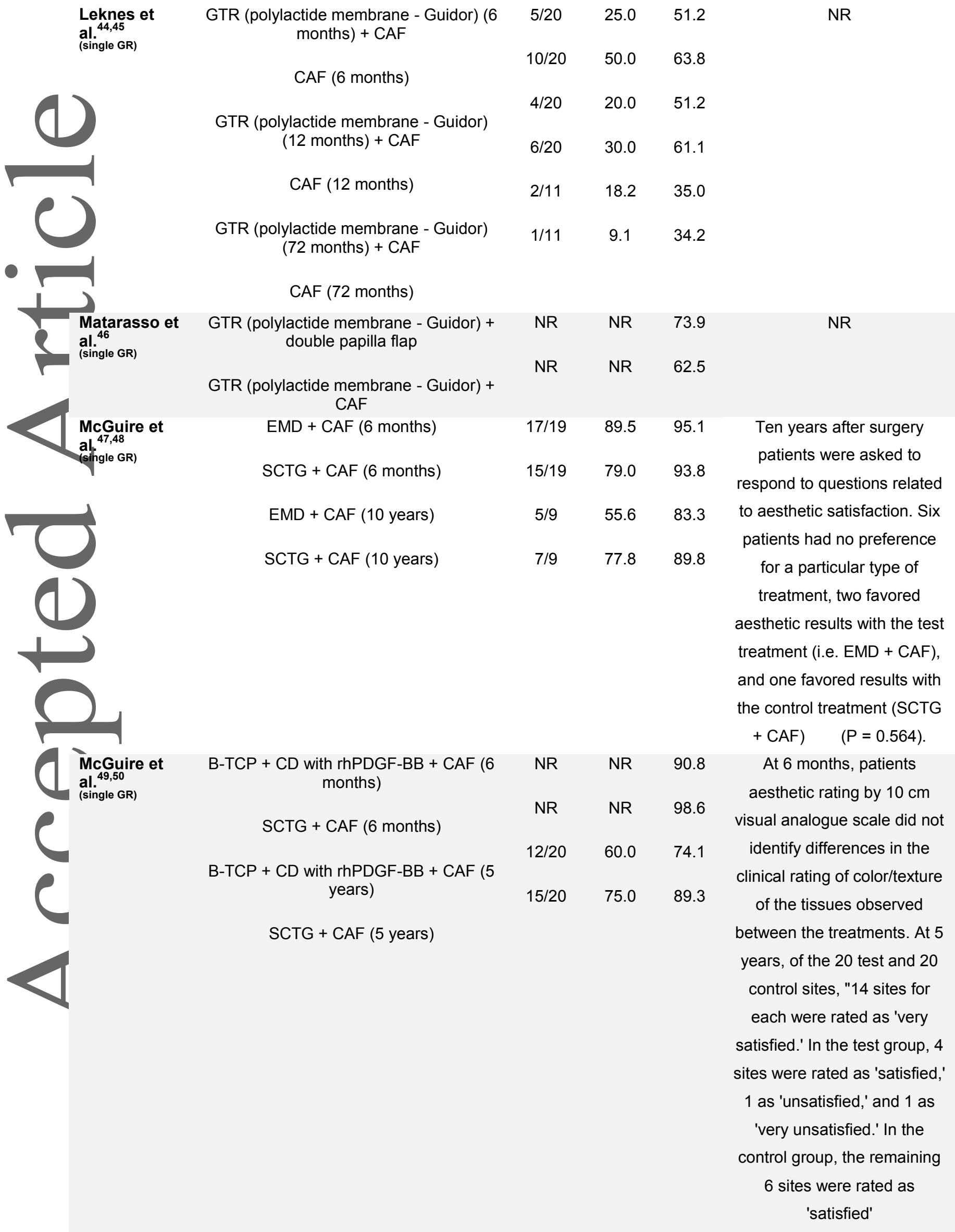




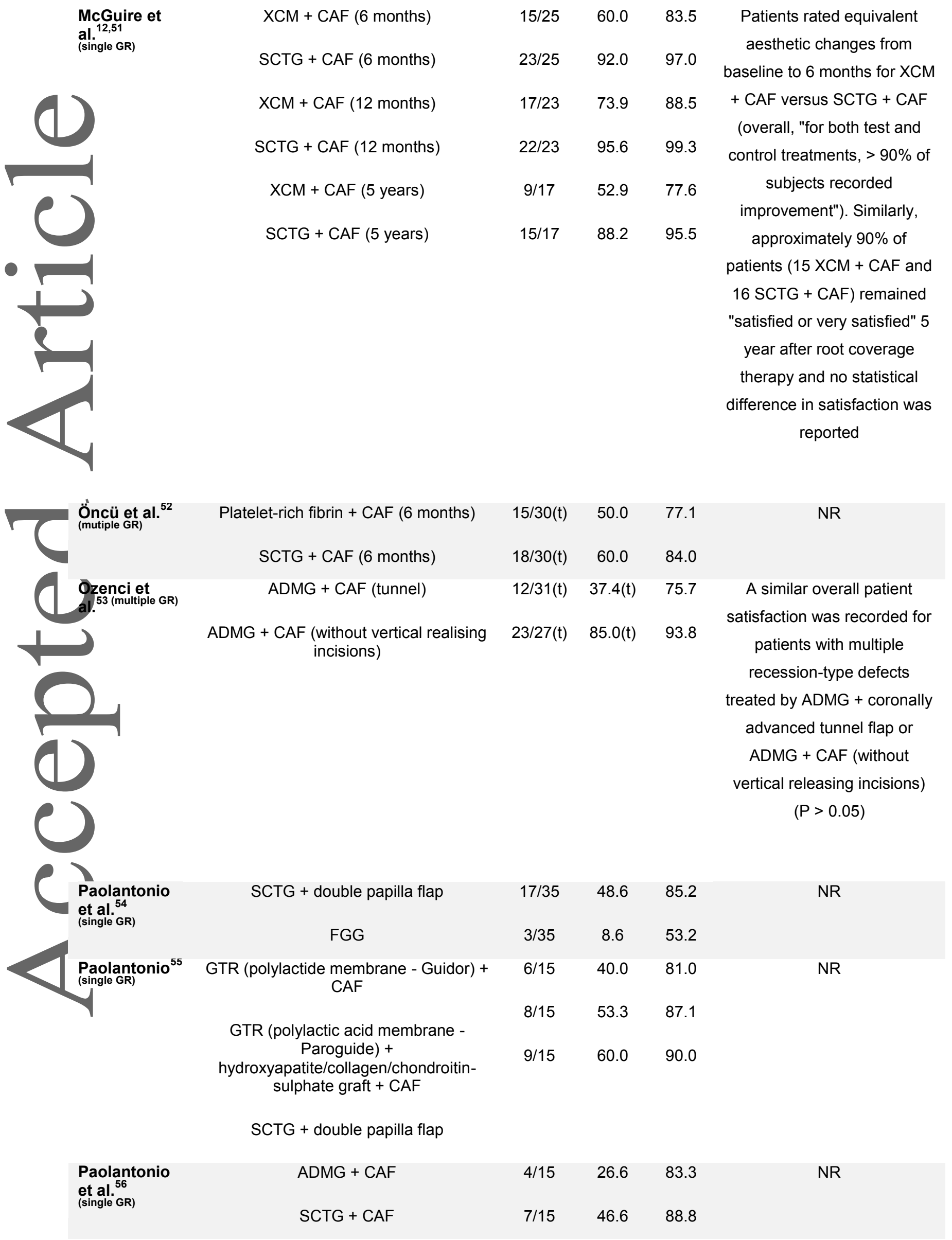

This article is protected by copyright. All rights reserved. 


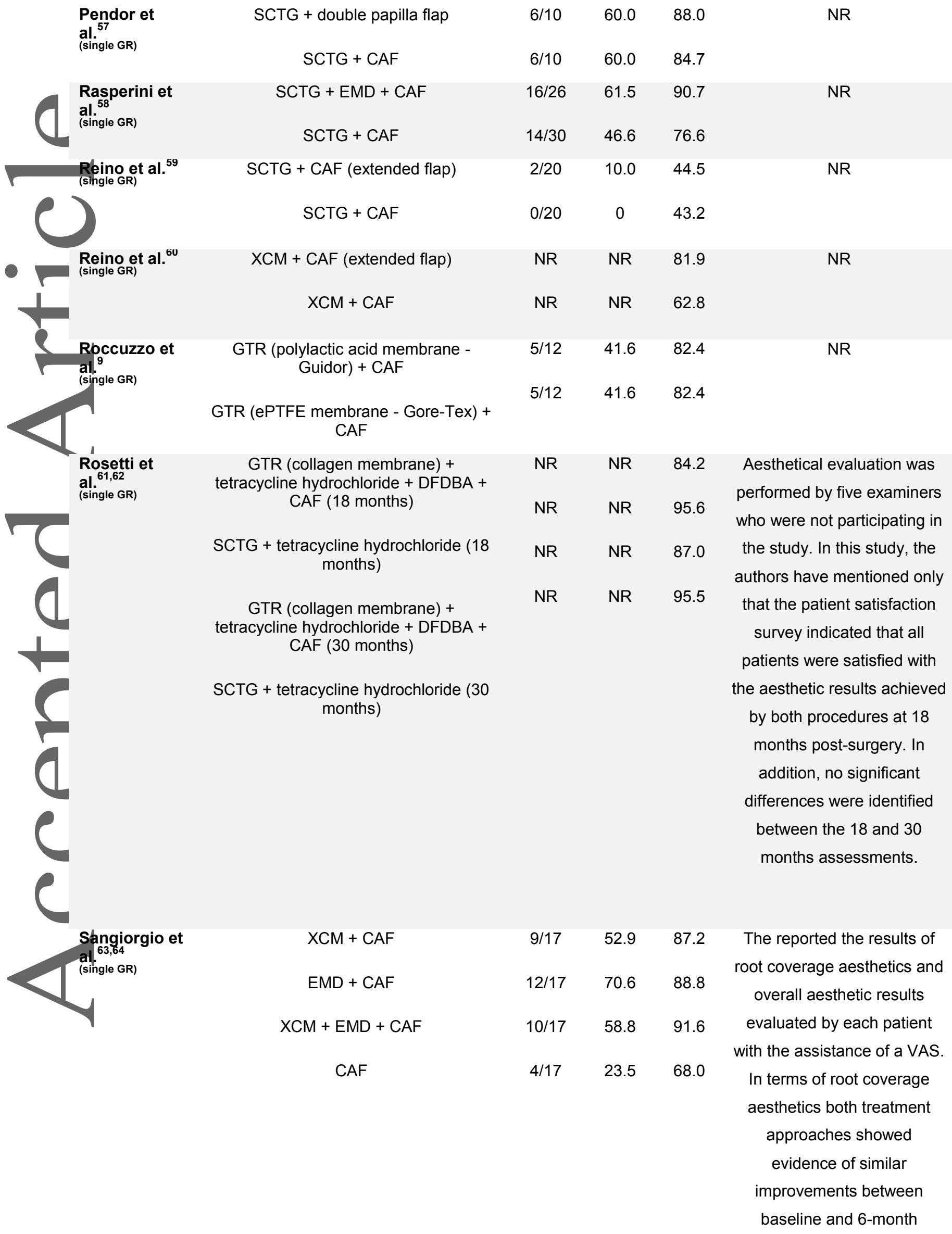

This article is protected by copyright. All rights reserved. 

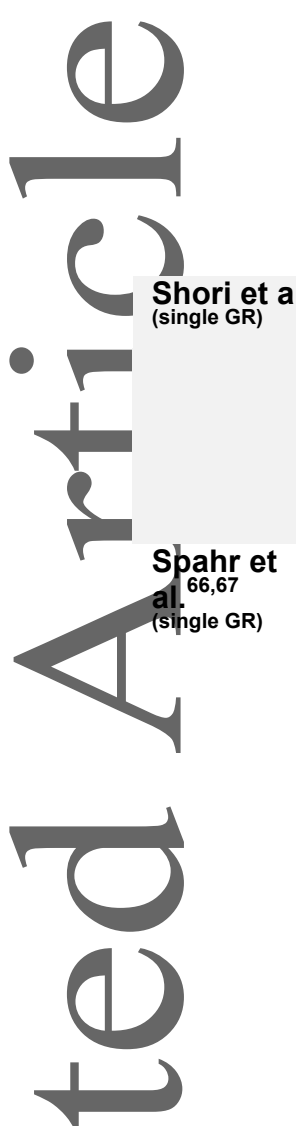

$$
\begin{aligned}
& \text { EMD + CAF (6 months) } \\
& \begin{array}{llll}
\text { Placebo (propylene glycol alginate) + } & \text { NR } & \text { NR } & 79.0
\end{array} \\
& \text { CAF (6 months) } \\
& \text { EMD + CAF (12 months) } \\
& \text { Placebo (propylene glycol alginate) + } \\
& \text { CAF (12 months) } \\
& \text { EMD + CAF (24 months) }
\end{aligned}
$$$$
\text { NR }
$$$$
\text { NR }
$$$$
80.0
$$$$
\text { NR }
$$$$
\begin{array}{lll}
N R & N R \quad 80.0
\end{array}
$$$$
\text { NR NR } \quad 79.0
$$$$
\text { NR } \quad 53.0 \quad 84.0
$$$$
\text { NR }
$$$$
23.0
$$$$
67.0
$$

Placebo (propylene glycol alginate) +

$$
\text { CAF (24 months) }
$$

Tozum et al. $^{68 \text { (single GR) }}$

$$
\text { SCTG + modified tunnel procedure }
$$

NR

NR

96.4

NR

$$
\mathrm{SCTG}+\mathrm{CAF}
$$

NR

NR

77.1

$$
\begin{gathered}
\mathrm{CAF}+\text { fibrin glue }+ \text { tetracycline } \\
\text { hydrochloride }
\end{gathered}
$$

63.1

NR

al. ${ }^{6}$

$\begin{array}{lll}2 / 11 & 18.2 \quad 52.9\end{array}$

$$
\text { CAF + tetracycline hydrochloride }
$$

Leukocyte- and platelet-rich fibrin + CAF (6 months) $\underset{\text { (multiple GR) }}{\text { Tunali et }}$

$$
\text { + CAF (6 months) }
$$$$
\text { Leukocyte- and platelet-rich fibrin + CAF }
$$$$
\text { (12 months) }
$$$$
4 / 22(t)
$$$$
18.2
$$$$
74.6
$$$$
\text { evaluation. Regarding overall }
$$$$
\text { aesthetic results following }
$$$$
\text { treatment, there was }
$$$$
\text { evidence of equivalent }
$$$$
\text { outcomes for all groups (i.e. }
$$$$
\text { similar aesthetics). }
$$

evaluation. Regarding overall
aesthetic results following
treatment, there was
evidence of equivalent
outcomes for all groups (i.e.






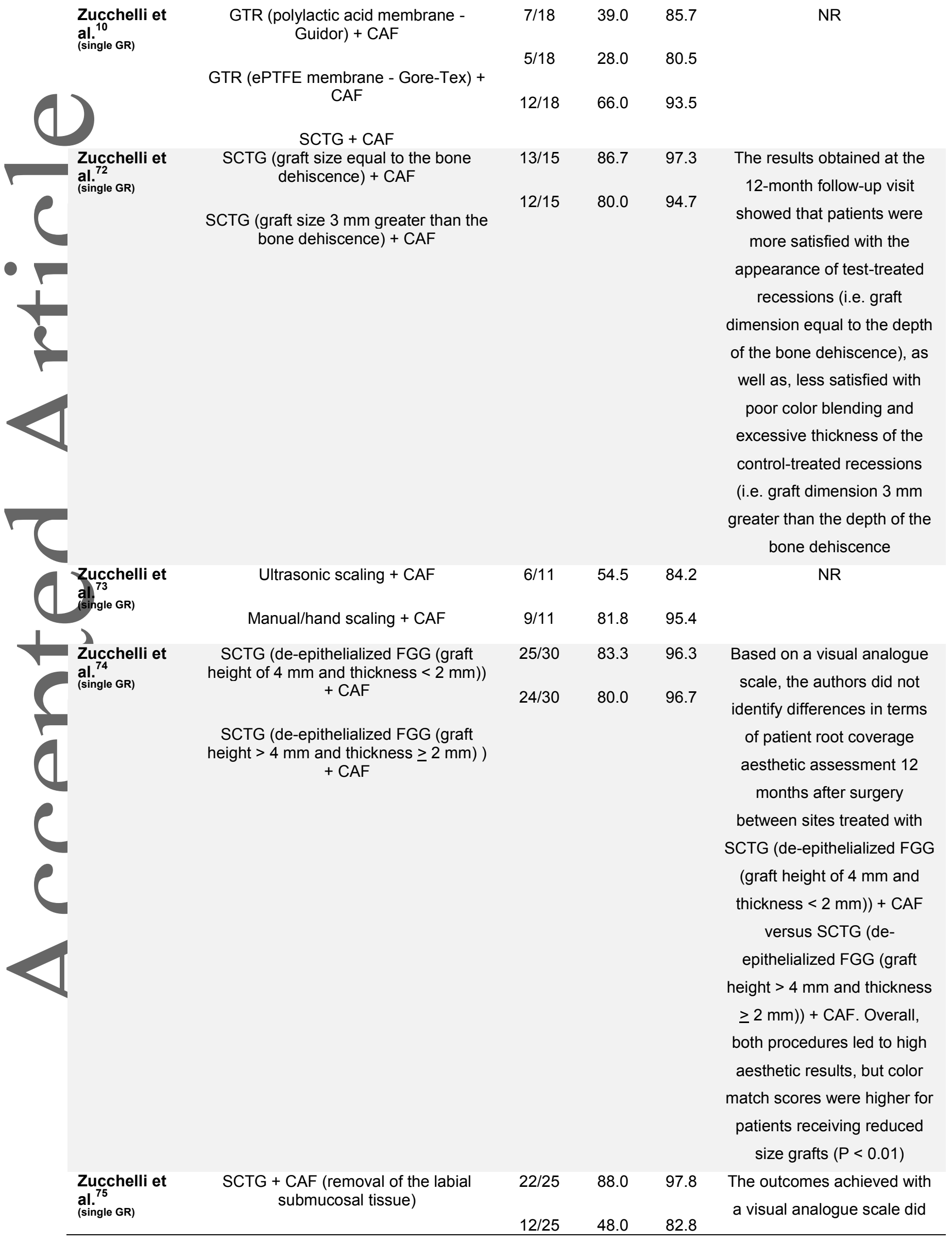

This article is protected by copyright. All rights reserved. 
Table 3 - Summary of meta-analyses

\begin{tabular}{|c|c|c|c|c|c|c|}
\hline Comparison & Outcome & Statistical method & Effect size & $\mathrm{Chi}^{2}$ & $P$ value (Q) & $\mathrm{I}^{2}(\%)$ \\
\hline $\begin{array}{l}\text { ADMG + CAF versus } \\
\text { SCTG + CAF } \\
\text { (single GR) }\end{array}$ & $\begin{array}{l}\text { GR depth change } \\
\text { CAL change } \\
\text { KT width change } \\
\text { SCRC }\end{array}$ & $\begin{array}{l}\text { MD 95\% Cl } \\
\text { MD 95\% Cl } \\
\text { MD 95\% Cl } \\
\text { OR } 95 \% \mathrm{Cl}\end{array}$ & $\begin{array}{c}-0.36(-1.03,0.30) \\
-0.53(-1.14,0.08) \\
-0.59(-1.27,0.10) \\
0.43(0.13,1.37)\end{array}$ & $\begin{array}{c}15.06 \\
9.73 \\
17.17 \\
0.00\end{array}$ & $\begin{array}{c}0.002 \\
0.02 \\
0.0007 \\
0.96\end{array}$ & $\begin{array}{c}80.0 \\
69.0 \\
83.0 \\
0\end{array}$ \\
\hline $\begin{array}{l}\text { ADMG + CAF versus } \\
\text { CAF }^{8,35} \\
\text { (single GR) }\end{array}$ & $\begin{array}{l}\text { GR depth change } \\
\text { CAL change } \\
\text { KT width change } \\
\text { SCRC }\end{array}$ & $\begin{array}{l}\text { MD 95\% Cl } \\
\text { MD 95\% Cl } \\
\text { MD 95\% Cl } \\
\text { OR } 95 \% \mathrm{Cl}\end{array}$ & $\begin{array}{l}0.61(-0.52,1.73) \\
0.51(-0.25,1.27) \\
0.28(-0.08,0.64) \\
3.97(0.20,80.50)\end{array}$ & $\begin{array}{l}7.45 \\
2.32 \\
0.30 \\
5.03\end{array}$ & $\begin{array}{l}0.006 \\
0.13 \\
0.59 \\
0.02\end{array}$ & $\begin{array}{c}87.0 \\
57.0 \\
0 \\
80.0\end{array}$ \\
\hline $\begin{array}{l}\text { EMD + CAF versus } \\
\operatorname{CAF}^{11,64,67}\left({ }^{*}\right) \\
(\text { single GR) }\end{array}$ & $\begin{array}{l}\text { GR depth change } \\
\text { CAL change } \\
\text { KT width change }\end{array}$ & $\begin{array}{l}\mathrm{MD} 95 \% \mathrm{Cl} \\
\mathrm{MD} 95 \% \mathrm{Cl} \\
\mathrm{MD} 95 \% \mathrm{Cl}\end{array}$ & $\begin{array}{c}0.07(-0.25,0.40) \\
0.22(-0.02,0.45) \\
0.35(0.13,0.56)\end{array}$ & $\begin{array}{l}5.62 \\
1.57 \\
0.64\end{array}$ & $\begin{array}{l}0.06 \\
0.46 \\
0.73\end{array}$ & $\begin{array}{c}64.0 \\
0 \\
0\end{array}$ \\
\hline 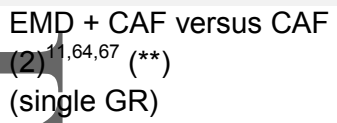 & $\begin{array}{l}\text { GR depth change } \\
\text { CAL change } \\
\text { KT width change }\end{array}$ & $\begin{array}{l}\text { MD 95\% Cl } \\
\text { MD 95\% Cl } \\
\text { MD 95\% Cl }\end{array}$ & $\begin{array}{l}0.32(0.10,0.55) \\
0.35(0.09,0.61) \\
0.40(0.17,0.62)\end{array}$ & $\begin{array}{l}2.10 \\
1.25 \\
1.63\end{array}$ & $\begin{array}{l}0.35 \\
0.53 \\
0.44\end{array}$ & $\begin{array}{c}5.0 \\
0 \\
0\end{array}$ \\
\hline $\begin{array}{l}\text { EMD + CAF versus } \\
\text { SCTG + CAF }{ }^{24,48} \\
\text { (single GR) }\end{array}$ & $\begin{array}{l}\text { GR depth change } \\
\text { CAL change } \\
\text { KT width change } \\
\text { SCRC }\end{array}$ & $\begin{array}{l}\text { MD 95\% Cl } \\
\text { MD 95\% Cl } \\
\text { MD 95\% Cl } \\
\text { OR } 95 \% \mathrm{Cl}\end{array}$ & $\begin{array}{c}-0.39(-1.27,0.48) \\
-0.25(-0.69,0.20) \\
-1.06(-1.36,-0.76) \\
0.61(0.05,7.86)\end{array}$ & $\begin{array}{c}25.79 \\
2.95 \\
2.47 \\
7.86\end{array}$ & $\begin{array}{c}<0.00001 \\
0.09 \\
0.12 \\
0.005\end{array}$ & $\begin{array}{l}96.0 \\
66.0 \\
59.0 \\
87.0\end{array}$ \\
\hline $\begin{array}{l}\text { GTR rm + CAF versus } \\
\text { SCTG + CAF } \\
\text { (single GR) }\end{array}$ & $\begin{array}{l}\text { GR depth change } \\
\text { CAL change } \\
\text { KT width change } \\
\text { SCRC }\end{array}$ & $\begin{array}{l}\text { MD 95\% Cl } \\
\text { MD 95\% Cl } \\
\text { MD 95\% Cl } \\
\text { OR } 95 \% \mathrm{Cl}\end{array}$ & $\begin{array}{c}-0.37(-0.60,-0.13) \\
0.35(0.06,0.63) \\
-1.77(-2.66,-0.89) \\
0.61(0.30,1.24)\end{array}$ & $\begin{array}{c}0.25 \\
0.93 \\
15.84 \\
2.01\end{array}$ & $\begin{array}{c}0.88 \\
0.63 \\
0.0004 \\
0.37\end{array}$ & $\begin{array}{c}0 \\
0 \\
87.0 \\
0\end{array}$ \\
\hline $\begin{array}{l}\text { GTR rm + CAF versus } \\
\text { GTR nrm + CAF } \\
\text { (single GR) }\end{array}$ & $\begin{array}{l}\text { GR depth change } \\
\text { CAL change } \\
\text { KT width change } \\
\text { SCRC }\end{array}$ & $\begin{array}{l}\text { MD 95\% Cl } \\
\text { MD 95\% Cl } \\
\text { MD 95\% Cl } \\
\text { OR } 95 \% \mathrm{Cl}\end{array}$ & $\begin{array}{c}0.23(-0.22,0.68) \\
0.12(-0.37,0.60) \\
0.12(-0.23,0.48) \\
1.33(0.46,3.85)\end{array}$ & $\begin{array}{l}1.59 \\
0.28 \\
0.03 \\
0.21\end{array}$ & $\begin{array}{l}0.21 \\
0.60 \\
0.86 \\
0.65\end{array}$ & $\begin{array}{c}37.0 \\
0 \\
0 \\
0\end{array}$ \\
\hline $\begin{array}{l}\text { GTR rm associated with } \\
\text { bone substitutes + CAF } \\
\text { versus SCTG + CAF } 55,61\end{array}$ & $\begin{array}{l}\text { GR depth change } \\
\text { CAL change } \\
\text { KT width change }\end{array}$ & $\begin{array}{l}\mathrm{MD} 95 \% \mathrm{Cl} \\
\mathrm{MD} 95 \% \mathrm{Cl} \\
\mathrm{MD} 95 \% \mathrm{Cl}\end{array}$ & $\begin{array}{l}-0.82(-2.13,0.49) \\
-0.52(-1.34,0.30) \\
-2.38(-2.84,-1.92)\end{array}$ & $\begin{array}{l}9.92 \\
2.72 \\
1.86\end{array}$ & $\begin{array}{c}0.002 \\
0.10 \\
0.17\end{array}$ & $\begin{array}{l}90.0 \\
63.0 \\
46.0\end{array}$ \\
\hline $\begin{array}{l}\text { GTR rm associated with } \\
\text { bone substitutes + CAF } \\
\text { versus GTR rm + } \\
\text { CAF }^{36,55} \\
\text { (single GR) }\end{array}$ & $\begin{array}{l}\text { GR depth change } \\
\text { CAL change } \\
\text { KT width change } \\
\text { SCRC }\end{array}$ & $\begin{array}{l}\text { MD 95\% Cl } \\
\text { MD 95\% Cl } \\
\text { MD 95\% Cl } \\
\text { OR } 95 \% \mathrm{Cl}\end{array}$ & $\begin{array}{c}0.48(0.09,0.88) \\
0.76(-0.01,1.54) \\
0.23(-0.21,0.68) \\
1.87(0.75,4.64)\end{array}$ & $\begin{array}{l}0.10 \\
2.83 \\
1.63 \\
0.03\end{array}$ & $\begin{array}{l}0.76 \\
0.09 \\
0.20 \\
0.87\end{array}$ & $\begin{array}{c}0 \\
65.0 \\
39.0 \\
0\end{array}$ \\
\hline $\begin{array}{l}X C M+C A F \text { versus } \\
C A F^{40,64} \\
\text { (single GR) }\end{array}$ & $\begin{array}{l}\text { GR depth change } \\
\text { CAL change } \\
\text { KT width change } \\
\text { SCRC }\end{array}$ & $\begin{array}{l}\text { MD 95\% Cl } \\
\text { MD 95\% Cl } \\
\text { MD 95\% Cl } \\
\text { OR } 95 \% \mathrm{Cl}\end{array}$ & $\begin{array}{c}0.40(0.11,0.68) \\
0.37(-0.09,0.83) \\
0.44(0.04,0.85) \\
4.73(2.35,9.50)\end{array}$ & $\begin{array}{l}0.86 \\
1.70 \\
1.16 \\
0.16\end{array}$ & $\begin{array}{l}0.35 \\
0.19 \\
0.28 \\
0.69\end{array}$ & $\begin{array}{c}0 \\
41.0 \\
14.0 \\
0\end{array}$ \\
\hline $\begin{array}{l}\text { PRF + CAF versus } \\
\text { SCTG + CAF } \\
\text { (multiple GR) }\end{array}$ & $\begin{array}{l}\text { GR depth change } \\
\text { CAL change } \\
\text { KT width change }\end{array}$ & $\begin{array}{l}\text { MD 95\% Cl } \\
\text { MD 95\% Cl } \\
\text { MD 95\% Cl }\end{array}$ & $\begin{array}{l}-0.01(-0.89,0.86) \\
-0.37(-0.69,-0.06) \\
-0.26(-0.98,0.45)\end{array}$ & $\begin{array}{c}14.71 \\
0.58 \\
13.41\end{array}$ & $\begin{array}{c}0.0001 \\
0.45 \\
0.0003\end{array}$ & $\begin{array}{c}93.0 \\
0 \\
93.0\end{array}$ \\
\hline
\end{tabular}

ADMG: acellular dermal matrix graft; CAF: coronally advanced flap; CAL: clinical attachment level; Cl: confidence interval; EMD: enamel matrix derivative; GR: gingival recession; GTR rm: guided tissue regeneration resorbable membrane; GTR nrm: guided tissue regeneration nonresorbable membrane; KT: keratinized tissue; MD: mean difference; OR: odds ratio; PRF: platelet-rich fibrin; SCRC: sites with complete root coverage; SCTG: subepithelial connective tissue graft; XCM: xenogeneic collagen matrix.

Authors' Note: Analyses were performed according to the follow-up evaluation (i.e. short term (6 months follow-up preferably) in the majority of comparisons, except for two comparisons: EMP + CAF versus CAF where the data were derived from short-term $\left(6 \text { months }^{64}\right)^{\star}$ and medium-term $\left(24 \text { months }{ }^{11,67}\right)^{\star *}$ measurements; and EMP + CAF versus SCTG + CAF where the data from mean changes from baseline (i.e. gingival recession, clinical attachment level and keratinized tissue width) were derived from short-term measurements, whereas sites with complete root coverage the data were derived from $6-$ month $^{48}$ and $24-$ month $^{24}$ measurements. 


\begin{tabular}{|c|c|c|c|c|c|c|c|}
\hline & 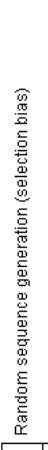 & 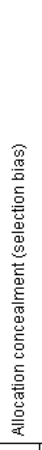 & 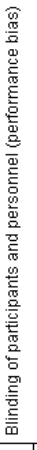 & 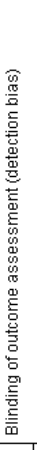 & 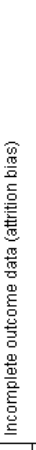 & 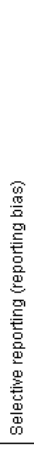 & 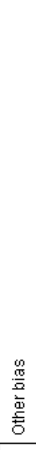 \\
\hline Abolfazli 2009 & $?$ & $?$ & $?$ & ๑ & ๑ & $\odot$ & 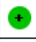 \\
\hline Ahmedbeyli 2014 & 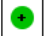 & $?$ & $?$ & $?$ & ๑ & ๑ & 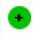 \\
\hline Ayub 2012 & $\odot$ & $\odot$ & $?$ & $?$ & ๑ & $\odot$ & † \\
\hline Babu 2011 & $?$ & $?$ & 3 & $?$ & † & $?$ & $\rightarrow$ \\
\hline Barros 2015 & (๑) & $?$ & $?$ & ๑ & ๑ & $\odot$ & $\odot$ \\
\hline Bouchard 1994 & $?$ & $?$ & $?$ & • & ๑ & $\odot$ &  \\
\hline Bouchard 1997 & $?$ & $?$ & $?$ & • & ๑ & $\oplus$ & $\rightarrow$ \\
\hline Costa 2016 & $?$ & $?$ & $?$ & ๑) & ๑ & † & † \\
\hline da Silva 2004 & $\odot$ & $?$ & $?$ & 단 & ๑ & $\odot$ & † \\
\hline Del Pizzo 2005 & $\odot$ & $?$ & $?$ & ๑ & $\odot$ & $\odot$ & $\odot$ \\
\hline de Queiroz 2006 & ๑ & $?$ & $?$ & $?$ & ๑ & ๑ & $\odot$ \\
\hline Dodge 2000 & $\odot$ & $?$ & $?$ & • & ๑ & $\odot$ & ๑ \\
\hline Henderson 2001 & $?$ & $?$ & $?$ & ๑ & ๑ & $\oplus$ & $\rightarrow$ \\
\hline Jaiswal 2012 & $\odot$ & $?$ & $?$ & $?$ & ๑ & † & † \\
\hline Jankovic 2010 & $\odot$ & $?$ & $?$ & ๑ & ๑ & + & 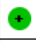 \\
\hline Jepsen 2013 & $\odot$ & $\odot$ & $?$ & ๑) & ๑ & † & 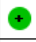 \\
\hline Joly 2007 & $\odot$ & $?$ & $?$ & ○ & ๑ & (†) & $\oplus$ \\
\hline Keceli 2008 & ○ & ○ & $?$ & ๑ & ๑ & † & † \\
\hline Kecelli 2015 & $\odot$ & $\odot$ & • & ๑ & ๑ & † & † \\
\hline Leknes 2005 & $\odot$ & $?$ & $?$ & () & ๑ & † & † \\
\hline Matarasso 1998 & \begin{tabular}{|l|}
$?$ \\
\end{tabular} & $?$ & $?$ & ○ & (†) & + & (†) \\
\hline McGuire 2012 & $\odot$ & + & $?$ & ๑ & ๑ & † & † \\
\hline McGuire 2014 & (†) & 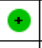 & $?$ & ๑) & † & 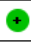 & (†) \\
\hline McGuire 2016 & $\oplus$ & + & $?$ & ๑ & ๑ & † & ๑ \\
\hline Öncü 2017 & $\odot$ & $?$ & 단 & ○. & ๑ & $\odot$ & ๑ \\
\hline Ozenci 2015 & $\odot$ & $?$ & $?$ & ๑ & ๑ & + & $\rightarrow$ \\
\hline Paolantonio 1997 & $\odot$ & $?$ & $?$ & 단 & ๑ & $\odot$ & ๑ \\
\hline Paolantonio 2002 & (๑) & $?$ & $?$ & ○ & ๑ & † & $\odot$ \\
\hline Paolantonio 2002b & $\odot$ & $?$ & $?$ & ๑ & ๑ & † & ๑ \\
\hline Pendor 2014 & $\odot$ & $?$ & $?$ & $?$ & ๑ & † & ๑ \\
\hline Rasperini 2011 & ๑ & ๑ & $?$ & $?$ & ๑ & † & $\odot$ \\
\hline Reino 2012 & $\odot$ & $?$ & $?$ & 단 & ๑ & $?$ & † \\
\hline Reino 2015 & $\odot$ & ๑ & $?$ & ๑ & ๑ & 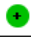 & $\odot$ \\
\hline Roccuzzo 1996 & $\odot$ & $?$ & $?$ & ๑) & ๑) & + & 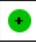 \\
\hline Rosetti 2013 & $\odot$ & $?$ & $?$ & ๑ & ๑ & † & ๑ \\
\hline Sangiorgio 2017 & $\odot$ & $\odot$ & ๑ & ๑ & ๑ & $\odot$ & † \\
\hline Shori 2013 & $\odot$ & $?$ & $?$ & $?$ & ๑ & † & † \\
\hline Spahr 2005 & 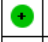 & $?$ & $?$ & ๑ & ๑ & † & † \\
\hline Tozum 2005 & 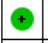 & $?$ & $?$ & ○ & ๑ & 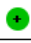 & $\odot$ \\
\hline Trombelli 1996 & $?$ & $?$ & $?$ & ๑ & ๑ & † & † \\
\hline Tunali 2015 & $\odot$ & $?$ & $?$ & ๑ & ๑ & † & ๑ \\
\hline Wang 2001 & $\odot$ & $?$ & $?$ & ๑ & ๑ & $\odot$ & ๑ \\
\hline Woodyard 2004 & $\odot$ & $?$ & $?$ & ๑ & ๑ & † & ๑) \\
\hline Zucchelli 1998 & $?$ & $?$ & $?$ & ๑ & ๑ & † & † \\
\hline Zucchelli 2003 & $\odot$ & $?$ & $?$ & ๑ & ๑ & $\odot$ & $\odot$ \\
\hline Zucchelli 2009 & $\odot$ & $?$ & $?$ & ๑ & ๑ & † & $\oplus$ \\
\hline Zucchelli 2014 & $\odot$ & $\odot$ & $?$ & ๑ & ๑ & $\odot$ & ๑ \\
\hline Zucchelli 2014b & $\odot$ & ๑ & $?$ & ๑ & ๑ & † & $\odot$ \\
\hline
\end{tabular}

This article is protected by copyright. All rights reserved. 
Figure 2: 'What's new' table - changes since the last version.

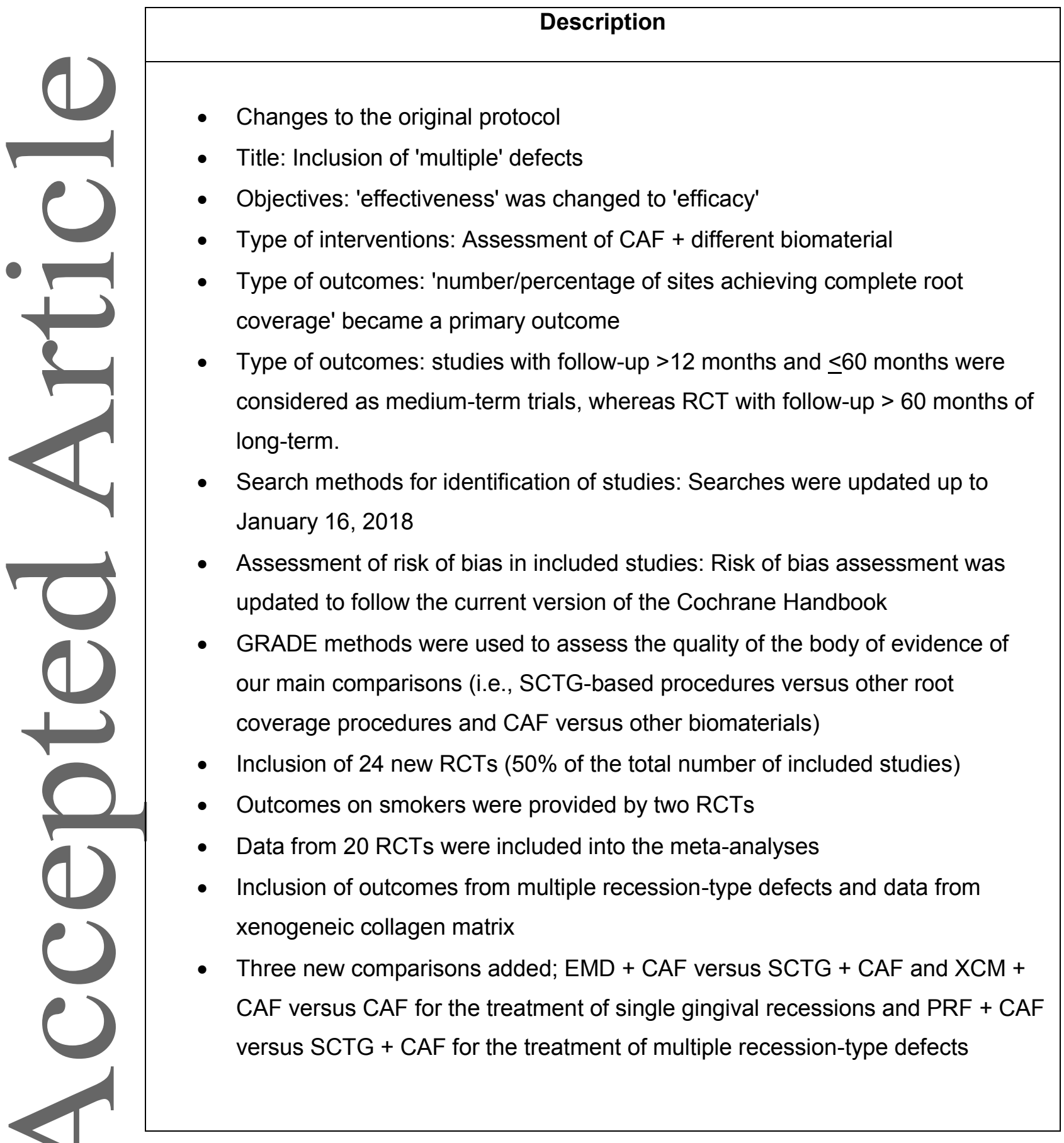

This article is protected by copyright. All rights reserved. 